NBER WORKING PAPER SERIES

\title{
TRADE COMPETITION AND THE DECLINE IN UNION ORGANIZING: EVIDENCE FROM CERTIFICATION ELECTIONS
}

\author{
Kerwin Kofi Charles \\ Matthew S. Johnson \\ Nagisa Tadjfar \\ Working Paper 29464 \\ http://www.nber.org/papers/w29464 \\ NATIONAL BUREAU OF ECONOMIC RESEARCH \\ 1050 Massachusetts Avenue \\ Cambridge, MA 02138 \\ November 2021
}

Do Lee, Anna Mather, Mitchell Ochse, and Jeremy Tang provided excellent research assistance. We thank Andrew Greenland for helpful comments and Alex Mas for sharing data. The views expressed herein are those of the authors and do not necessarily reflect the views of the National Bureau of Economic Research.

NBER working papers are circulated for discussion and comment purposes. They have not been peer-reviewed or been subject to the review by the NBER Board of Directors that accompanies official NBER publications.

(C) 2021 by Kerwin Kofi Charles, Matthew S. Johnson, and Nagisa Tadjfar. All rights reserved. Short sections of text, not to exceed two paragraphs, may be quoted without explicit permission provided that full credit, including $(\subset$ notice, is given to the source. 
Trade Competition and the Decline in Union Organizing: Evidence from Certification Elections Kerwin Kofi Charles, Matthew S. Johnson, and Nagisa Tadjfar

NBER Working Paper No. 29464

November 2021

JEL No. F16,J41,J50,J51,J52

\section{ABSTRACT}

We assess whether and why trade competition partly explains the sharp decline in U.S. workers' attempts to organize labor unions in recent decades. We find that between 1990-2007, import competition due to the "China Shock" lowered union certification elections by $4.5 \%$ among workers in manufacturing industries directly exposed to it, and by $8.8 \%$ among workers indirectly exposed through its effect on their local labor market. Consistent with a simple model of workers' decision to seek union representa-tion, we show that direct exposure lowered the expected wage gain from unionization, whereas indirect exposure increased the cost of job loss, both of which discourage worker organizing.

Kerwin Kofi Charles

School of Management

Yale University

165 Whitney Avenue

New Haven, CT. 06511

and NBER

kerwin.charles@yale.edu

Matthew S. Johnson

Duke University

Box \#90312

Durham, NC 27708

m.slater.johnson@gmail.com
Nagisa Tadjfar

Massachusetts Institute of Technlogy

ntadjfar@mit.edu 


\section{Introduction}

Private sector workers in the U.S. seeking to form a labor union at their job must first conduct and win a union certification election, overseen by the National Labor Relations Board (NLRB). ${ }^{1}$ One of the most dramatic changes in the U.S. labor market over the past several decades has been a pronounced decline in workers' attempts to unionize. Figure 1a shows that from a rate of 4.3 elections per 100,000 non-union workers in 1984, by 2009 the rate had fallen to only 0.75 per 100,000 non-union workers. A massive literature suggests that unions increase their members' wages (Farber et al., 2018; Freeman and Medoff, 1984) and other compensation (Knepper, 2020), and there is ample survey evidence that unions enjoy consistently favorable esteem, both in the public at large ${ }^{2}$ and among workers (Kochan et al., 2019). Why, then, are ever-fewer workers trying to unionize? What forces in the economy have driven changes in workers' expected benefits and costs from union organizing? Virtually no work in the voluminous economics literature on labor unions directly empirically analyzes workers' organizing attempts and the success of those efforts. This paper attempts to partially fill this gap.

We study how, and by what mechanisms, import competition from China has affected union organization efforts. Figure $1 \mathrm{~b}$ shows that the acceleration of Chinese imports around the year 2000 coincided with an acceleration in the decline in the rates of union elections. Furthermore, Chinese imports were concentrated in manufacturing industries (Acemoglu et al., 2016), a traditional bastion of unionization. Together these suggestive patterns hint at a causal connection. On the other hand, union election rates have declined nearly as quickly in non-manufacturing as they have in manufacturing (Figure 1c), leading some to doubt that Chinese imports appreciably affected unionization efforts (Mishel et al., 2020). Convincing

\footnotetext{
${ }^{1}$ If 30 percent of workers in a proposed bargaining unit express support for union representation, the NLRB conducts a secret ballot election; if a majority of workers vote favorably, the NLRB certifies the union as the sole representative of the bargaining unit. In rare cases, some employers voluntarily choose to recognize a union without a NLRB certified election.

${ }^{2}$ Jeffery M. Jones, "As Labor Day Turns 125, Union Approval Near Record High," Gallup, August 28, 2019. https://news.gallup.com/poll/265916/ labor-day-turns-125-union-approval-near-year-high. aspx.
} 
evidence for a causal effect of the "China shock" on union elections must thus account not only for falling organization attempts in manufacturing but also among workers in sectors not directly exposed to import competition — something our paper does.

Our analysis distinguishes between two channels whereby the China shock might affect workers' organizing decision. The direct influence on a worker comes from the adverse effect of Chinese trade competition on the profitability or economic strength of the worker's firm. Import competition's indirect influence on a worker operates through the adverse effect of rising Chinese import penetration on the profitability of import-exposed firms in the labor market where the worker lives, irrespective of the type of firm where he works.

We empirically assess the direct and indirect effects of Chinese import competition on union certification elections, using detailed information on every union certification election certified by the NLRB since 1990. Building on the work of Acemoglu et al. (2016), we proxy for the strength of the direct influence on workers by the extent of their industry's exposure to the China shock. The size of the indirect influence on workers is measured by the degree of trade exposure of all firms in the local labor market, which we define as Commuting Zones. We use geo-coding and fuzzy linking methods to match the election data to measures of industries' and local labor markets' trade exposure. To estimate the causal effect of the China shock, we follow several prior studies and estimate Two Stage Least Squares (TSLS) models, in which we instrument for industry-level Chinese import penetration to the U.S. with the import levels of the same industries in other advanced countries. We assess the robustness of this approach using a separate identification strategy, pioneered by Pierce and Schott (2016), to measure industries' exposure to Chinese imports.

We find that both direct and indirect exposure to the China Shock significantly lowered union organizing efforts. A 1 percentage point increase in an industry's import penetration led to a 3 percent decrease in rates of new union elections per worker in that industry from 1990-2008. This estimate is highly statistically significant and robust to alternative specifications. Using information on the voting outcomes in elections that occurred, we find 
a similarly-sized negative effect on successful union elections in which the union won.

Examining next the indirect channel, we estimate that a 1 percentage point increase in the average import penetration rate of industries in a local labor market led to roughly 23 percent fewer union elections. ${ }^{3}$ The effect is similar for successful union elections. Furthermore, this effect is present for workers in sectors not themselves directly exposed to import competition, confirming that our estimate captures the effect of indirect exposure, and that our CZ-level measure is not merely re-purposing the measures of direct exposure.

Based on a simple counterfactual exercise, our estimates imply that there would have been 4.5 percent more union elections 1990-2007 in manufacturing industries had there been no industry exposure to the China Shock, and 8.8 percent more elections in all industries had there been no geographic exposure to the shock.

What explains these estimated effects? We present a simple framework of a worker's decision whether to organize for a union that formalizes insights first developed in Ashenfelter and Pencavel (1969). Our framework highlights two distinct forces through which any economic shock, including growing Chinese import competition, affects a worker's organizing decision. The first of these forces operates through the expected benefits that workers anticipate from organizing. A worker has a higher desire to attempt to unionize the larger the gap between the wage she would expect to earn as a unionized worker and her current non-unionized wage. Because the China shock lowered the profitability of firms in industries directly exposed to import competition (Autor et al., 2020), workers at those firms should have expected a reduction in the rents a union could bargain over, and thus in their expected unionized wage. We hypothesize that this force explains the negative estimated direct effect of industry exposure on certification elections.

The second force our framework highlights stems from the increased risk of job loss and having to seek work elsewhere that a worker might face because of union organizing. ${ }^{4}$ Local

\footnotetext{
${ }^{3}$ As we discuss below, while this estimate of the effect of CZ-level exposure is an order of magnitude larger than the corresponding estimated effect of industry-level exposure, the two estimates are much closer when re-scaled by the standard deviation of CZ-level and industry-level exposure, respectively.

${ }^{4}$ There are two main reasons why attempting to organize a union might increase job loss risk. One, as
} 
labor markets with many firms in import-exposed industries experienced lower employment rates and a reduction in market wages (Autor et al., 2013). Workers in such markets should thus be hesitant to organize because of the difficulty of finding alternative employment were they to lose their jobs. Importantly, this consideration affects both workers whose jobs are directly affected by China and workers whose firms or industries are unaffected. We hypothesize that this force accounts for the large negative estimated indirect effect of local labor market exposure on certification elections.

To assess the empirical support for our framework's two hypothesized mechanisms, we use newly-quantified data on the negotiated wages in every collective bargaining agreement by private-sector unions since 1990. We first explore whether direct exposure to the China Shock shrinks the wage gains that unions are able to secure in negotiations, thereby making new organizing less appealing to workers. For each contract settlement between a union and its employer in the manufacturing sector, we calculate the change in the employer's Chinese import exposure (based on its industry) since the last time a contact was negotiated, typically a period of three years. We find that a 1 percentage point increase in annualized Chinese import penetration of an employer's industry led the typical union to negotiate a 0.12 percent lower wage increase.

We next examine whether local labor market exposure to the China shock widened the gap between a worker's current wage and the prevailing wage in the market where she works (what we call her "alternative wage"). Matching union contract settlements to the employer's Commuting Zone, we first verify that for the majority of workers, labor market exposure to increased Chinese import competition had no detectable adverse effect on union-negotiated wage increases. ${ }^{5}$ However, replicating and extending evidence from (Autor et al., 2013),

predicted by standard theory, is that raising wages above competitive levels (presumably the main aim of a union's activities), should lead to reductions in labor demand. Secondly, although such actions violate the law, there is evidence that employers often retaliate against workers who engage in union organizing activity (Abowd and Farber, 1990; McNicholas et al., 2019; Stansbury, 2021).

${ }^{5}$ This non-effect is consistent with models of rent-sharing in unionized firms (Abowd and Lemieux, 1993): direct exposure to import competition of other firms in the same labor market does not necessarily affect available rents at a given firm. 
we show that labor markets with many exposed firms experienced substantial market wage reductions, especially in non-manufacturing industries, presumably due to outward shifts in labor supply. Taken together, these results imply that workers living in markets heavily affected by trade competition faced a higher cost of job loss.

These extended results help explain our main findings about the estimated effects of direct and indirect exposure to import competition on union organizing. The negative estimated effect from direct exposure to the China shock is consistent with a reduction in expected wage gains from unionization in industries adversely affected by trade competition. The much larger estimated effect from indirect exposure to the trade shock is consistent with the loss of alternative job opportunities in communities heavily affected by China shock making workers reluctant to raise their risk of job loss by organizing.

Our findings are not only of independent interest, but also extend previous work in important ways. Although labor economists have had a long-standing interest in understanding the determinants of union organizing and union membership, there have been few empirical papers on the subject. Older empirical studies used times series data to link aggregate trends in union membership to variables like unemployment ((Ashenfelter and Pencavel, 1969; Sheflin et al., 1981).Using data on individual worker votes in a handful of NLRBcertified elections, Farber and Saks (1980) found that the likelihood that a worker voted positively on a union certification election was inversely related to their relative position in the wage distribution. Lazear (1981) developed a model of how various factors determine the rates of unionization at the industry or occupation level. In the only other paper of which we are aware that empirically analyzes the determinants of union organizing, Abowd and Farber (1990) find that union organizing activity at the industry level is positively associated with the availability of quasi-rents per worker, but they note a puzzling relationship that union organizing exhibits a downward trend even controlling for available quasi-rents. Our paper sheds insight on this puzzle by considering the role of changes in a worker's outside options, as well as the expected wage gain from becoming unionized at the current job, in 
driving the decision to organize.

Trade, including the China import competition shock that we study, has long been proposed as a critical driver in workers' union organizing efforts (e.g. Slaughter (2007) and Hirsch (2008)). However, previous work has a) primarily focused on the effects of trade on unionization within manufacturing, whereas our paper examines its indirect effect on all sectors, and b) almost exclusively sought to determine how trade affects the overall unionization rate by changing the relative mix of the stock of already-unionized versus non-unionized jobs in the economy, whereas our paper assesses how trade affects new union organizing via certification elections.

In a related paper, Ahlquist and Downey (2019) investigate the effects of Chinese import exposure on the stock of unionized workers. They find that industries more exposed to Chinese import competition saw slightly larger reductions in the share of unionized workers. Of course, this finding could arise either from lower rates of new organizing which our paper documents, or from shifts in total employment across already unionized versus non-unionized employers. However, they find that states more exposed to import exposure experienced higher rates of unionization outside manufacturing, whereas we find that Commuting Zones (local labor markets) more exposed to import penetration experienced lower rates of union organizing. ${ }^{6}$ We complement their analysis by using more detailed industry codes (357 4digit SIC codes vs. 64 Census Industry codes), a finer level of geography (722 Commuting Zones vs. 50 states), and by considering union organizing, which is arguably more tightly linked to the theoretical concern of worker's demand for unionization.

Section 2 describes the data we use to estimate the direct and indirect effects of import competition on the frequency and success of union elections, and Section 3 presents the empirical strategy and results. To shed light on the mechanisms behind these results, we present a simple model of a worker's decision to organize to form a union in Section 4. Section

\footnotetext{
${ }^{6}$ Ahlquist and Downey (2019) present evidence that their finding that geographic exposure to the China Shock raised unionization rates is explained by women in exposed labor markets shifting from low-union retail sector to the high-union healthcare and education sectors.
} 
5 presents the data we use to test these mechanisms as well as the associated empirical evidence.

\section{Data and Measures}

To examine the direct and indirect effects of Chinese import competition on labor union organizing, we need measures of industries' and local labor markets' exposure to Chinese import competition, as well as data on union organizing election efforts. We discuss the data sources we use for each of these purposes, in turn.

\subsection{Measuring Industrial and Geographic Exposure to Chinese Import Competition}

China's emergence as a great power in international trade began in the early 1990s following a series of reforms, and accelerated further when China joined the World Trade Organization in 2000 (Autor et al., 2013). Because China's exports were concentrated in certain industries, there was substantial variation in how exposed U.S. industries were to Chinese import competition. Furthermore, because of regional variation in industrial composition, there was also substantial variation in the degree to which different local labor markets were exposed to this "China Shock." To empirically capture these two dimensions of the trade competition shock, we use measures that build upon the widely-known work by Autor et al. (2013) and Acemoglu et al. (2016). In robustness extensions to our main results, we instead use measures of exposure developed by Pierce and Schott (2016). We only briefly describe these data and methods since detailed descriptions may be found in published papers. Reassuringly, as we show later, our findings are essentially unaffected by which of the previous literature's measures of industry or labor market exposure we use. 


\subsubsection{Industry Exposure}

Following previous work, our measure of industry $k$ 's exposure to Chinese import penetration for industry $k$ over time period $\tau$ in the US is:

$$
\Delta I P_{k \tau}^{c u}=\frac{\Delta M_{k \tau}^{c u}}{Y_{k 1991}+M_{k 1991}-X_{k 1991}}
$$

Here, $\Delta I P_{k \tau}^{c u}$ is the change in import penetration from China $(c)$ to the US $(u)$ for industry $k$ over period $\tau$. To calculate this variable, we divide $\Delta M_{k \tau}^{c u}$, the change in Chinese imports to the US in industry $k$ over period $\tau$, by the US market volume in 1991 for industry $k$, which is the sum of $Y_{k 1991}$ (US industry shipments in 1991) and $M_{k 1991}-X_{k 1991}$ (the net imports in $k$ in 1991). When we use this measure in (1) as an explanatory variable in our regressions, we annualize it by multiplying $\Delta I P_{k \tau}^{c u}$ by a factor of $\frac{1}{\tau}$.

An issue with using $\Delta I P_{k \tau}^{c u}$ for estimation is that realized US imports from China might reflect industry demand shocks. In this case, OLS estimates with $\Delta I P_{k \tau}^{c u}$ as an explanatory variable would be biased if, for example, unobserved industry-level demand raises both imports as well as employment prospects that directly affect unionization efforts. Consistent with the convention that has emerged in studies analyzing the China shock, we instrument for US exposure to Chinese import penetration using the increase in imports from China over period $\tau$ to a set of comparison countries:

$$
\Delta I P_{k \tau}^{c o}=\frac{\Delta M_{k \tau}^{c o}}{Y_{k 1988}+M_{k 1988}-X_{k 1988}}
$$

Here, $\Delta I P_{k \tau}^{c o}$ is the change in import penetration from China $(c)$ to eight other advanced countries (o) for industry $k$ over period $\tau$. On the right-hand side, $\Delta M_{k \tau}^{c o}$ is the change in imports from China in industry $k$ over period $\tau$ to the comparison countries Australia, 
Denmark, Finland, Germany, Japan, New Zealand, Spain, and Switzerland. We divide $\Delta M_{k \tau}^{c o}$ by the US market volume, defined above, in 1988.

Using files assembled by Autor et al. (2013), we create a dataset that includes $\Delta I P_{k \tau}^{c o}$ and $\Delta I P_{k \tau}^{c u}$ for each 4-digit manufacturing industry across every subperiod between the years 1991 through 2007. We link data on international trade for 1991-2007 from the UN Comtrade Database $^{7}$ to a slightly aggregated set of 4-digit SIC codes (as explained in more detail in Acemoglu et al. (2016)), so that our final data set contains 392 manufacturing industries.

\subsubsection{Local Labor Market Exposure}

To measure a local labor market's exposure to Chinese import penetration, we follow many prior studies to measure local labor markets as Commuting Zones (CZs), or clusters of adjacent counties that have the commuting structure of a local labor market (Tolbert and Sizer, 1996). Following Acemoglu et al. (2016), we measure exposure of each CZ $j$ as the average change in Chinese import penetration over period $\tau$ across industries located within a CZ, weighted by the share of each industry $k$ in the CZ's initial employment:

$$
\Delta I P_{j \tau}^{C Z}=\sum_{k} \frac{L_{j k t}}{L_{j t}} \Delta I P_{k \tau}^{c u}
$$

In this expression, $t$ is the start year of period $\tau$ and $L_{j k t}$ is the employment in industry $k$, in $\mathrm{CZ} j$, in year t. $\Delta I P_{k \tau}^{c u}$ is as defined in Equation 1. As before, we instrument $\Delta I P_{j \tau}^{C Z}$ with the corresponding industry-level import penetration across the eight comparison countries:

$$
\Delta I P_{j \tau}^{c o}=\sum_{k} \frac{L_{j k 1988}}{L_{j 1988}} \Delta I P_{k \tau}^{c o}
$$

where $L_{j k 1988}$ is the employment in industry $k$ in $\mathrm{CZ} j$ in 1988 as computed from the CBP.

\footnotetext{
${ }^{7}$ See http://comtrade.un.org/db/default.aspx
} 
We obtain data on local industry employment structure from the County Business Patterns (CBP). These data were also used by Autor et al. (2013), who only considered CZ employment for the years 1980, 1990, and 2000. Because, as described below, we consider multiple periods of exposure $\tau$, we expand the CBP dataset to include data on employment for the years 1988 and all years 1991-1999 and 2001-2007. We impute employment by county by 4-digit SIC code for each year using the same approach as Autor et al. (2013); see their paper for more details on the exact methodology.

\section{$2.2 \quad$ NLRB-certified Union Elections}

We use data from the National Labor Relations Board (NLRB) on every union election from 1960-2009. For each election, we observe information including the employer name and address, broad industry classification, and outcome of each election. ${ }^{8}$ We geocode the address of each election to obtain its county, and we used a county-Commuting Zone crosswalk to obtain its Commuting Zone. ${ }^{9}$

The election data only includes the broad sector of the affected establishment. To measure industry-level exposure of the establishment tied to an election, which is at the level of 4digit SIC industry codes, we linked the elections data to the National Establishment Time Series (NETS) database using fuzzy matching methods. ${ }^{10}$ NETS is an annual panel data set extracted from Dun \& Bradstreet data that seeks to include all establishments ever in operation since 1990. From NETS, we obtained each establishment's Data Universal Numbering System (DUNS) number, a unique establishment identifier. For elections for which we were unable to fuzzy match to NETS, research assistants manually obtained the DUNS number of the election's associated establishment. ${ }^{11}$. For both of these groups, we used this DUNS number to obtain the associated 4-digit SIC code from NETS. Finally, for

\footnotetext{
${ }^{8}$ We thank Alex Mas for sharing these data with us.

${ }^{9}$ This crosswalk is from David Dorn's website, available at https://www.ddorn.net/data.htm.

${ }^{10}$ Specifically, we used the Stata package reclink2 (Wasi and Flaaen, 2015), and we used multiple rounds of matching on employer name, address, city, state, and 2-digit SIC or NAICS industry code.

${ }^{11}$ This information was from www.dnb.com
} 
the small remainder of elections for which research assistants could not find a DUNS number, they obtained the establishment's 4-digit SIC code from a combination of the Lexis Nexis database, www.manta.com, www.mailinglists.com, and www.siccode.com. We successfully linked $90 \%$ of elections in the elections dataset to either a DUNS number, 6-digit NAICS code, or 4-digit SIC code obtained through the other means. ${ }^{12}$

From these data, we create a measure of the number of union elections in each 4-digit SIC industry, and in each Commuting Zone, in each decade (from 1990-1999, and from 20002007). Table 1 describes summary statistics for the union election data and our measures of import penetration.

\subsection{Other Data}

We obtain data from other sources for additional control variables in our analysis. We measure the initial extent of unionization from unionstats.com, a website maintained by Barry T. Hirsch and David A. Macpherson, which uses data from the Current Population Survey Monthly Outgoing Rotation Group (CPS-MORG) to estimate unionization rates for various units of analysis (Hirsch and Macpherson, 2003). We use two data sets from this database: one with data on overall 1989 unionization rates in each state and another with 1989 unionization rates in each Census Industry Code (CIC) nationally. We convert these CIC codes to the 4-digit SIC codes used in the rest of our analysis using a 1990 Census to 4-digit SIC crosswalk from David Dorn's data page. ${ }^{13}$ Because CIC codes do not correspond one-to-one with 4-digit SIC codes, we take the mean of the various unionization rates that correspond to the same SIC code.

\footnotetext{
${ }^{12}$ One concern we had is that the several research assistants who performed the manual linking might not be consistent in their approach. To assess this concern, we drew a random sample of 100 elections and had multiple research assistants link that same subset. Research assistants arrived at an identical industry classifications for $94 \%$ of elections in this subset, indicating that lack of consistency was not in fact a practical concern.

${ }^{13} \mathrm{https}: / /$ www.ddorn.net/data.htm
} 


\section{Direct and Indirect Effects of Import Competition on Union Organizing Efforts}

The growth of Chinese import competition in the 1990s and 2000s substantially reduced new union organizing through both direct industry exposure and indirect local labor market exposure. We describe these results in turn.

\subsection{Effect of Industry Trade Exposure on New Union Certification Elections}

To assess how industry exposure to the China Shock affected new union organizing, we estimate the following regression:

$$
\ln \left(\text { elect }_{k \tau}\right)=\beta_{1} \Delta I P_{k \tau}^{c u}+\gamma_{\tau}+F(k)+\beta_{2} X_{k 0}+\epsilon_{k \tau}
$$

The dependent variable, $\ln \left(\right.$ elect $\left._{k \tau}\right)$, is the annualized number of union certification elections in industry $k$ over period $\tau$ divided by the number of workers in $k$ at the start of period $\tau$; we annualize this measure by dividing by the number of years in period $\tau . \Delta I P_{k \tau}^{c u}$ and $\gamma_{\tau}$ are as before, and $X_{k 0}$ is start-of-period industry-level controls, which include industry $k$ 's initial unionization rate in 1989. As has become conventional, we define $\tau$ as either 1990-1999 or 2000-2007, and we stack the data so that a unit of observation represents an industry-decade $(k \tau){ }^{14}$

Table 2 presents the regression results. The estimates reveal that industries with greater exposure to Chinese import competition experienced fewer new union certification elections. The results are quite stable across specifications that add a progressively longer set of con-

\footnotetext{
${ }^{14}$ That is, the period 1990-1999, we calculate the number of elections elections that took place in any year including and between 1990 and 19999, and we measure trade exposure using annualized $\Delta I P_{k \tau}^{c u}$ and $\Delta I P_{k \tau}^{c o}$ with $\tau=1999-1991$. Similarly, for elections that take place in any year including and between 2000 and 2007 , we use $\tau=2000-2007$.
} 
ditioning variables: year fixed effects only (Column 1); industry initial unionization rate (Column 2); and 1-digit SIC fixed effects (Column 3). Using the estimate in Column 3, a 1 percentage point increase in industry-level Chinese import penetration leads to 2.5 percent fewer union elections per worker over the same period $(p=0.013)$. In Column 4 , we replace the number of total elections with the number of successful union elections per worker (elections in which the union is victorious). The point estimate is essentially unchanged, suggesting that the China Shock had little effect on voting outcomes conditional on an election being held.

Overall, these results indicate that workers in industries directly exposed to Chinese import competition were less likely to seek union certification by quantitatively important amounts.

\subsection{Effect of Local Labor Market Exposure on New Union Certi- fication Elections}

To estimate the indirect effect of local labor market exposure to import competition on workers' union organizing efforts, we estimate:

$$
\ln \left(\text { elect }_{j \tau}\right)=\beta_{1} \Delta I P_{j \tau}^{C Z}+\gamma_{\tau}+\gamma_{r(j)}+\beta_{2} X_{j 0}+\epsilon_{j \tau}
$$

Similar to $(4), \ln \left(\right.$ elect $\left._{j \tau}\right)$ is the $\log$ of the number of union certification elections in $\mathrm{CZ} j$ over period $\tau$ divided by the number of workers in $j$ at the start of period $\tau$. All other variables are as previously defined.

Table 3 presents the results. The table shows results for regression specifications that control for decade fixed effects only (Column 1), plus the 1989 state unionization rate (Column 2), plus Census Region fixed effects (Column 3), plus a control for the percent of the initial CZ workforce employed in manufacturing (Column 4). The estimates are remarkably stable and are consistently negative and strongly statistically significant. The point estimate 
in Column 4 implies that a one percentage point increase in CZ-level import penetration over a decade leads to 23 percent fewer union certification elections over that decade in the CZ $(\hat{\beta}=-.256, \exp (-.259)-1=-.228, p<.01) .{ }^{15}$

These local labor market estimates are intended to capture the effect of "indirect" exposure: how workers' organizing efforts are affected when other firms in their local labor market face import competition. However, within manufacturing specifically, our measure of local labor market exposure also reflects the degree to which firms faced differential direct exposure.

To isolate indirect exposure, we follow Acemoglu et al. (2016) and split industries into three mutually exclusive categories: Exposed, Non-Exposed Tradeable, and Non-Exposed NonTradeable. The Exposed sector includes manufacturing industries for which predicted import exposure rose by at least 2 percentage points between 1991 and 2011, as well as all industries for which the predicted full upstream import exposure measure increased by at least 4 percentage points over 1991-2011. All other industries are "non-exposed." Tradeable industries, which include manufacturing, agriculture, forestry, fishing and mining, are traded on global markets, and their aggregate demand is unlikely to be affected by a negative shock to the local labor market. Non-Tradeable industries, which encompasses all other industries, include services, some of which (such as construction) could experience a reduction in aggregate demand due to a contraction in local economic activity.

Given these definitions, we adapt Equation 5 as follows:

\footnotetext{
${ }^{15}$ The coefficients in this table are an order of magnitude larger than those in Table 2 estimating the effects of industry exposure. However, these tables are not directly comparable. As shown in Table 1, the mean and standard deviation of industry-level import exposure are much larger than the mean and standard deviation of CZ-level exposure. Put another way, a one-percentage point increase in industry-level exposure represents a roughly $0.6 \mathrm{SD}$ increase, whereas a one-percentage point increase in CZ-level exposure represents a roughly 8 SD increase.
} 


$$
\begin{aligned}
\ln \left(\text { elect }_{j \tau}\right)= & \beta_{1} \Delta I P_{j \tau}^{C Z} \times \mathbb{1}\{\text { Exposed }\}_{k}+ \\
& \beta_{2} \Delta I P_{j \tau}^{C Z} \times \mathbb{1}\{\text { Non-Exposed Tradeable }\}_{k}+ \\
& \beta_{3} \Delta I P_{j \tau}^{C Z} \times \mathbb{1}\{\text { Non-Exposed Non-tradeable }\}_{k}+ \\
& \sum_{\substack{i=\text { Exposed, } \\
\text { Non-exptradable, } \\
\text { Non-expnon-tradable }}} \mathbb{1}\{i\}+\gamma_{t}+\gamma_{r(j)}+F(k)+\beta_{2} X_{j 0}+\epsilon_{j k t},
\end{aligned}
$$

Table 4 reports estimates of the differential effects of local exposure to import penetration by sector. Greater local exposure has a particularly pronounced negative effect on new elections in the Exposed sector, but it also leads to fewer elections in both non-exposed sectors. The point estimates in Column 1 imply that one percentage point increase in local exposure leads to a 50 percent decrease in new union elections in the Exposed sector $(p<.01)$, a 22 percent

decrease in the Non-exposed Tradeable sector $(p=0.023)$, and a 31 percent decrease in the Non-Exposed Non-Tradeable sector $(p=0.011)$. These results are largely robust across columns with the inclusion of additional controls, though the estimate for the Non-exposed Tradeable sector attenuates somewhat in magnitude and is (barely) no longer significant at the $10 \%$ level in Column 4 when we control for the percent employed in manufacturing $(p=0.123)$.

These results reveal that workers in local labor markets that faced exposure to Chinese import competition were less likely to organize for union representation, and that much of this effect can be attributed to indirect exposure.

\subsection{How Much of the Decline in Union Elections Can the China Shock Explain?}

Our results in Sections 3.1 and 3.2 show that Chinese import competition reduced rates of union organizing, both directly via industry exposure and indirectly via local labor market 
exposure. How much of the evolution of the incidence of union organizing over this time period do these two forces explain?

To answer this question, we amend an approach in Acemoglu et al. (2016) to conduct a simple counterfactual exercise that asks how many more union elections there would have been during 1990-2007 a) among manufacturing industries, had there been no industry exposure to Chinese imports, and b) among all industries, had there been no local labor market exposure to Chinese imports.

To calculate the counterfactual with no industry exposure among manufacturing industries, we first construct an estimate of the number of elections per 10,000 workers in each industry $j$ that would have existed in the absence of industry exposure to the China Shock, which we estimate as follows:

$$
\text { Elections }_{j, \tau}^{c f}=\text { Elections }_{j, \tau}^{\text {observed }} * e^{-\left(\frac{\tau}{100} * \hat{\beta_{1}} * R^{2} * \Delta I P_{j t}\right)} .
$$

In the above expression, $\hat{\beta}_{1}$ is the 2SLS coefficient from the industry-level regression on union elections. $\Delta I P_{j t}$ is the observed increase in import penetration between 1991 and year $t$ for industry $j$, and $R^{2}$ is the adjusted R-squared of the first stage regression which has a numerical value of 0.56 : the expression $\Delta I P_{j t} * R^{2}$ is the increase in import penetration that we attribute to China's improving competitive position in industry $j$ between 1991 (or 1999) and year $t$ (Acemoglu et al., 2016).

We then calculate the difference between the observed elections at the end of period (2007 or 1999) and the counterfactual elections in 2007 or 1999 shown in Equation 7 . We compute a weighted mean (with weights equal to each industry's employment level) of this difference to generate our estimate of how much higher the rate of union elections would have been in manufacturing industries had there been no industry exposure to China.

For a counterfactual estimate of the number of union elections that would have occurred 
had there been no local labor market exposure, we conduct the same calculations as above, except that $j$ now represents a commuting zone rather than an industry.

Table 5 summarizes the results of this exercise. In Panel A, we consider how many elections there would have been across manufacturing industries had there been no industry exposure to Chinese import competition, separately for the periods 1990-1999 and 20002007. The first row reveals that there were 3.08 union elections per 10,000 workers in manufacturing industries between 1990-1999. Had Chinese import competition remained unchanged over this period, we estimate there would have been 0.12 more elections per 10,000 workers, or $3.59 \%$ more than the observed number of elections. The difference between the actual and predicted counterfactual number of elections grew to 5.97\% during 2000-2007, consistent with the observed increase in Chinese imports after the year 2000.

Panel B considers how many elections there would have been across all commuting zones in the 48 contiguous states (and D.C.) had there been no local labor market exposure to Chinese import competition. As the rightmost column shows, we see that the counterfactual increase in elections is roughly double the magnitude of the industry effects. Had the import competition faced by commuting zones remained unchanged over this period, there would have been $7.35 \%$ more union elections 1990-1999, and $11.2 \%$ more elections $2000-2007$.

\subsection{Robustness of Results to Different Measure of Exposure}

Pierce and Schott (2016) use a different approach from Acemoglu et al. (2016) to measure US industries' exposure to Chinese imports. Reassuringly, our implications of the effects of direct and indirect exposure to import penetration on union elections are essentially unchanged using this approach.

Pierce and Schott (2016) leverage the policy change in 2001 in which the U.S. granted China permanent Normal Trade Relations (NTR) in 2001, which eliminated the risk that tariffs on Chinese goods would revert back to higher levels. The impact of PNTR can be thought of as "rise in tariffs that would have occurred in the event of a failed annual 
renewal." Importantly, this policy change differentially affected different industries, leading to wide variation in the "NTR gap" across industries, defined by:

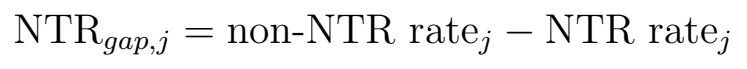

where $j$ is an industry. Large NTR gaps means greater disincentive for trade with China pre-PNTR which means more trade after PNTR. We use a crosswalk to map the industry codes used by Pierce and Schott (2016) to the 392 SIC codes in our analysis.

We adapt the difference-in-difference regression specification in Pierce and Schott (2016) to estimate the effect of Chinese import competition on rates of union elections for industry $i$ following the 2001 policy reform to estimate:

$$
\ln \left(\text { elect }_{i t}\right)=\theta \text { PostPNTR }_{t} \times N T R G a p_{i}+\gamma \text { PostPNTR }_{t} \times X_{i}+\delta_{1 \text { digitSIC }}+\delta_{t}+\epsilon_{i t},
$$

where our control $X_{i}$ is state unionization rate in 1989 and $\delta_{1 \text { digitSIC }}$ are 1-digit SIC fixed effects, and $\delta_{t}$ are year fixed effects.

To examine the effect of local labor market exposure to Chinese import competition, we follow Pierce and Schott (2020) who compute county-level exposure to PNTR as the employment-share-weighted-average "NTR gap" across 4-digit SIC industries in the active county:

$$
\operatorname{NTR~} \operatorname{gap}_{c}=\Sigma_{j} \frac{L_{j c}^{1990}}{L_{c}^{1990}} * \mathrm{NTR}_{\operatorname{gap}_{j}}
$$

where $c$ represents counties. We repeat the above calculation at the commuting zone level. We adapt their specification to estimate:

$$
\ln \left(\text { elect }_{c t}\right)=\theta \text { PostPNTR } R_{t} \times N T R G a p_{c}+\gamma \text { PostPNTR } R_{t} \times X_{c}+\delta_{\text {census }}+\delta_{t}+\epsilon_{c t}
$$

where our control $X_{c}$ are state unionization rate in 1989, percent of initial CZ workforce 
employed in manufacturing, and $\delta_{\text {census }}$ are census region fixed effects, and $\delta_{t}$ are year fixed effects.

The results shown in Tables A1 and A2 corroborate our earlier findings using measures and specifications based on Acemoglu et al. (2016). The estimates in Table A1 show that industries that saw a larger decline in their implied tariffs due to PNTR saw significantly fewer union elections after 2001. Table A2 shows that commuting zones more exposed also saw a significant decline in union elections and — as we found in our prior specification — with a magnitude that is meaningfully larger than industry exposure.

\section{A Worker's Decision to Seek Union Representation}

Why did Chinese import competition lower union certification attempts, both among workers in directly exposed industries and among workers indirectly exposed in their local labor market? We present a simple theoretical formalization of a worker's decision to seek unionization and organize a certification election. This framework highlights two key factors - one a benefit; the other an expected cost - that under-girds this decision. We assess how direct and indirect exposure to Chinese import competition affects organizing through the effects on these two factors.

We consider a worker, currently employed and not a member of a labor union, who is weighing whether to organize to hold a certification election to become unionized. ${ }^{16}$ We abstract from the question of the likelihood that an election is successful and assume that if a worker's bargaining unit organizes to hold an election, the union will win with probability one. This simplifying assumption affects none of the main insights forthcoming from the formal framework.

A worker's decision to organize will depend, in part, on the presumed benefits of union membership. The most salient such benefit is the wage premium he can expect as a unionized

\footnotetext{
${ }^{16}$ Our framework extends and somewhat formalizes Ashenfelter and Pencavel (1969)'s model of the determinants of the growth in the unionization rate. While that paper was focused on modelling union growth, we explicitly consider the decision to organize for a union.
} 
worker, relative to the wage he currently earns as a non-union worker. A long literature has consistently found that this "union wage premium" is between 10 and 20 percent (Card, 1996; Farber et al., 2018). Union membership can also bring improvements of other forms of compensation, including higher pension contributions (Knepper, 2020). We assume that the worker currently earns a wage of $w_{c}$ at his non-unionized job and anticipates that if the job were unionized it would pay $w_{u}>w_{c}$.

The worker weighs the benefit of organizing against its various costs. Some of these costs are logistical like the opportunity cost of time spent attending organizing meetings or the monetary costs of union dues; we represent such costs, collectively, by $k$.

Another cost of organizing, and the one on which we focus, is that seeking a certification election might increase the probability that a worker loses his job. This higher job loss risk could come from multiple sources. To the extent that unions extract rents from employers and reduce firms' valuation (Lee and Mas, 2012), unionized employers may be more likely to lay off workers. Indeed, successful union elections are associated with decreased likelihood of establishment survival and lower employment at surviving establishments (Frandsen, 2021). Furthermore, though we have abstracted from the possibility of an unsuccessful union campaign, employers frequently fire workers in retaliation for union organizing (Farber, 1987; Abowd and Farber, 1990; Bronfenbrenner, 2009; Stansbury, 2021). ${ }^{17}$ We normalize the probability of job loss to be zero if a worker remains non-unionized; if the worker seeks union certification, he keeps his (newly unionized) job with probability $p_{i} \in\{0,1\}$ and loses his job with probability $1-p_{i}$.

This higher risk of job loss is costly. A large literature, pioneered by Jacobson et al. (1993), illustrates that job loss is associated with a sustained and meaningful reduction in workers' earnings. This reduction in earnings could reflect loss of a firm-specific premium,

\footnotetext{
${ }^{17}$ While such retaliatory firing is technically illegal under the National Labor Relations Act (NLRA), firms in practice face little incentive to comply with this law. There is no meaningful legal penalty for firms that violate this law. The NLRA can only issue "make-whole" remedies to compensate a fired-worker for losses incurred because of the employer's actions. There is no legal scope to subject firms to financial penalties or for criminal liability. Given these weak incentives, it is unsurprising that there is much evidence of widespread noncompliance with the NLRA (Stansbury, 2021).
} 
firm-specific human capital or match-specific benefits (Lachowska et al., 2018), among other factors. To capture this "cost of job loss," we assume that a worker's "alternative wage" $w_{a}-$ the wage he would earn if he loses his job-is lower than his current wage, so $w_{a}<w_{c}<w_{u}$.

Given this set up, we can write the worker's expected wage if he organizes as

$$
E(\text { wage } \mid \text { organize })=p_{i} w_{u}+\left(1-p_{i}\right) w_{a}-k
$$

And his expected wage if he does not organize as simply

$$
E(\text { wage } \mid \text { not organize })=w_{c} .
$$

The worker chooses to organize if and only if

$$
p_{i} w_{u}+\left(1-p_{i}\right) w_{a}-k>w_{c} .
$$

Or, rearranging terms, if:

$$
p_{i}\left(w_{u}-w_{c}\right)+\left(1-p_{i}\right)\left(w_{a}-w_{c}\right)-k>0 .
$$

The first term on the left side in (8) represents the union wage premium-the increase in the wage a worker can expect if he successfully organizes his workplace to be unionizedmultiplied by the probability that he keeps his (newly unionized) job. The second term on the left side (which is negative) represents cost of job loss - the wage decrease a worker will experience in the event of job loss, relative to his current wage - multiplied by the probability that he loses his current job. 


\subsection{Chinese Import Competition and the Organizing Decision}

Does this framework help explain the empirical results in Section 3? We propose that, viewed through the lens of our framework, greater industry exposure to Chinese import competition constituted a negative shock to the union wage premium, and greater local labor market exposure - for most workers - primarily exacerbated the cost of job loss. We discuss our rationale for these arguments in turn.

\subsubsection{Industry Exposure as a Shock to the Union Wage Premium}

Firms operating in industries more exposed to the surge in Chinese import competition experienced lower sales, profitability, and patenting (Autor et al., 2020). Given this evidence, a worker whose employer was directly exposed to the China Shock would plausibly expect a lower union wage premium. One way that unions bargain for wage increases above and beyond the "market" wage is by extracting quasi-rents from employers; indeed, prior studies reveal that changes in firm-level quasi-rents lead to changes in union-negotiated wages (Abowd and Lemieux, 1993) and the union wage premium (Rose, 1987). The reduction in sales, employment, profitability, and rent-inducing innovation in directly exposed firms plausibly reduced the size of quasi-rents, thus reducing the union wage premium. Below, we assess whether industries more exposed to import competition saw smaller negotiated union wage gains. If present in the data, this pattern would suggest that the benefits of union representation declined in these industries, potentially explaining why fewer workers in them sought union representation via a certification election.

\subsubsection{Local Labor Market Exposure as a Shock to the Cost of Job Loss}

Local labor markets with an initial industry mix that rendered them more exposed to Chinese import competition experienced substantial deterioration in employment prospects, including losses in employment rates primarily in manufacturing industries (Acemoglu et al., 2016), 
Furthermore, more exposed local labor markets experienced a substantial decline in average wages, particularly in non-manufacturing sectors not directly exposed to import competition (Autor et al., 2013; Bloom et al., 2019), likely due to outward shifts in labor supply.

How do these effects relate to our theoretical framework? In contrast to direct industry exposure, it is unlikely that indirect local labor market exposure to import competition would affect the wage gains that labor unions were able to win in contract negotiations. Consider a union bargaining with an employer in chemical manufacturing (a tradeable industry not exposed to Chinese import competition). Because the firm sells a good traded on a global market, a contraction of activity in nearby firms has no effect on its demand nor its overall quasi-rents. The story is similar for a non-tradeable industry, such as a nursing home. ${ }^{18}$ As union bargaining outcomes are largely determined by the quasi-rents available to be shared between the employer and union (Abowd and Lemieux, 1993; Rose, 1987), it is plausible that union wages would effectively be shielded from exposure to the China Shock among proximate firms.

However, indirect exposure through one's local labor market clearly affects the second force in our model: the cost of job loss. A worker losing her job in a local labor market in which other firms were heavily exposed to the China Shock can expect a longer duration of joblessesness (due to the deterioration in employment prospects) and a lower expected wage when she finds a new job (because of the reduction in the market wage). Combined, these results imply that the cost of job loss increased substantially for workers in local labor markets more highly exposed to Chinese import competition. Through the vantage point of our framework, this higher cost of job loss would lead fewer workers to seek union representation via a certification election.

\footnotetext{
${ }^{18}$ However, for some non-tradeables, a contraction in local activity could reduce their demand, and thus reduce quasi-rents.
} 


\section{Why Did Import Competition Lower Union Orga- nizing Efforts?}

Above we proposed that direct industry exposure to Chinese import competition led to lower union organizing by reducing the union wage premium, and that indirect local labor market exposure led to lower organizing by increasing the cost of job loss. Using data on the outcomes of collective bargaining agreements between private-sector unions and their employers, we find evidence consistent with these two mechanisms.

\subsection{Data on Union Contract Settlements}

We obtained summaries of every collective bargaining agreement between private-sector employers and labor unions over the years 1991-2008 from the Bloomberg Bureau of National Affairs (BNA) Labor Plus database. For each contract settlement, we observe the settlement year, employer name, union name, the employer's broad industry classification, ${ }^{19}$ city and state(s) where the contract was negotiated, the number of workers covered by the contract, the contract expiration date, and a textual summary of the negotiated wage and benefit changes.

Each observation represents an employer-union-bargaining unit-contract settlement. For some analyses, it is useful to identify repeat observations of the same employer-union dyad; however, there is no standardized employer (or employer-union) ID. In Appendix A, we describe in detail how we identify repeat observations of the same employer-union dyad. Among all employer-union dyads, the mean number of contracts we observe is 1.4 contracts; among those dyads that we observe more than once, the mean number of contracts is 3.0 contracts. Some contract durations were specified in months rather than years. We converted these month-based contract durations to years and rounded them to the nearest integer.

\footnotetext{
${ }^{19}$ Sectors observed include: Mining, Construction, Manufacturing, Transportation, Communications, Electric, Gas, Sanitary Services, Wholesale Trade, Retail Trade, Finance, Insurance, Real Estate, Services, and Public Administration.
} 
Across all contracts, the mean contract duration, defined this way, is 3 years.

Importantly for our purpose, the data contain a text summary of the amount of negotiated wage increases as well as any other non-wage provisions included in the contract such as pensions and healthcare packages. Because these measures were text summaries, we had to take several processing steps to convert them to numeric values for our empirical analysis. We provide a brief description of this process here, with more details in Appendix A.

To process the text in the contracts, we first trimmed the clauses to preserve only the sections with numeric information. Next, we split the contract clause into two components. The first component is the "main" clause that corresponds to annual increases in the baseline wage expressed either as a percentage or dollar increase in hourly, weekly, monthly, or yearly pay. We parsed this first component from the text by searching for indexed years such as "1st" "2nd" and "3rd", keywords such as "initially", specific years such as "2004", or commaseparated sequential values. The second component corresponds to one-time, lump-sum payments. We parsed this component using keywords such as "supplemental", "incentive", "lump-sum", "bonus", "cash payment", "merit", and "premium." 20

After parsing the textual information from the contracts, we constructed a variable measuring the wage increase negotiated in a contract that is the sum of two components: a main wage increase and any remaining wage increases in the form of bonuses or other lump-sum payments.

Table 6 displays summary statistics for the data on contract settlements, and Figure A1 provides a histogram of wage increases over all contract settlements in our sample period. Since this variable exhibits right skew, we use its log as our main dependent variable (first adding the lowest non-zero wage increase to accommodate the few cases in which a contract negotiated for a wage increase of zero). Our results are essentially identical (in percent

\footnotetext{
${ }^{20} \mathrm{We}$ also sought to extract only payments that are guaranteed to current employees. As such, we omit numbers associated with keywords in the contract such as "future new hire rates," "profit sharing gains," "payments conditional on accidents or safety incidents," "holiday or weekend premium," "graduate school reimbursements," or "seniority based payments." We also restrict our analysis to extract only full-time rates and discard part-time rates.
} 
terms) if we instead use the un-logged percent wage change.

\section{Assignment of Contracts to SIC Classifications}

To examine the effects of industry-level exposure on union bargaining outcomes, we must overcome the hurdle that most contracts only listed the employer's industry or sector at a level coarser than 4-digit SIC. Some contracts did include 4-digit SIC codes, enabling us to directly link them to the industry-level exposure defined in Equation 1. Others had 6-digit NAICS codes; for these we use the weighted crosswalk from Acemoglu et al. (2016) to map NAICS 1997 6-digit to SIC 1987 4-digit industry codes. The majority of contracts only included SIC and NAICS codes at the 1- or 2-digit level. To map these data to 4-digit SIC codes, research assistants used a similar approach as with union elections to either manually obtain the 4-digit SIC code or to identify the associated DUNS number from www.dnb.com. Some establishments corresponded to more than one DUNS number and hence multiple industry classifications. For these establishments, we use the industry classification that has the highest import exposure. ${ }^{21}$

\section{Assignment of Contracts to Commuting Zones}

To examine the effects of local labor market exposure to import competition on union bargaining outcomes, we map the contract settlements to 722 Commuting Zones $(\mathrm{CZs})$ that cover the entire US mainland. The contract settlements provided data on the state(s) and city (or cities) in which the establishments are located. Some contracts spanned geographic units larger than cities such as metro areas, states, multiple states, Census regions, or even nationwide.

For those contracts that corresponded to a unique city-state, we geocoded the latitudes and longitude of the city centroid and mapped it to the county in which the centroid is located. For contracts with more expansive geographic coverage, a research assistant manually

\footnotetext{
${ }^{21} 45$ contracts were manually linked by research assistants to SIC codes that do not exist. We omit these contracts for the industry-level analysis but consider them in the geography-level analysis.
} 
identified all of the FIPS county codes that belonged to the geographic level in the contract. We excluded contracts that were "nationwide" or simply "multi-state" from this approach. Among the contracts we matched to a county or counties, the mean contract mapped to 8 counties and the median contract mapped to 1 county.

We used the same county-CZ crosswalk to map contracts to Commuting Zones as we did for the union elections, and we then transformed our data set to be at the level of an employer-union-contract-CZ. For employer-union-contracts that corresponded to multiple $\mathrm{CZs}$, we treat each employer-union-contract-CZ unit as a separate observation. Because contracts that cover many $\mathrm{CZs}$ are unlikely to be affected by labor market conditions in a single CZ, in our main analysis we restrict attention to contracts that cover five or fewer CZs (roughly $94 \%$ of contracts). ${ }^{22}$

\subsection{Effect of Industry Trade Exposure on Union-Negotiated Wage Increases}

We first assess if unions representing workers in highly-exposed industries negotiated for relatively smaller wage increases, leading to smaller expected union wage premia.

Because unions secure wage increases via contract settlements, and each contract is valid for a specified time period, the change in industry exposure most relevant is the change since the prior contract was negotiated. Our estimating equation is:

$$
\ln \left(w_{k d t}\right)=\beta_{1} \Delta I P_{k \tau}^{c u}+\gamma_{t}+\gamma_{d}+F(k)+\epsilon_{k d t},
$$

where $\ln \left(w_{k d t}\right)$ is the log of the percent wage increase negotiated in a contract negotiated in year $t$ by a union-employer dyad in industry $k$, located in Census division $d . \Delta I P_{k \tau}^{c u}$, the change in U.S. import penetration from China for industry $k$ over the prior $\tau$ years, is as

\footnotetext{
${ }^{22}$ Our results are unchanged if we change the cutoff of the number CZs covered in a contract to be less than or more than five. Results available from the authors upon request.
} 
defined in Equation 2. As described above, we instrument $\Delta I P_{k \tau}^{c u}$ with $\Delta I P_{k \tau}^{c o}$ : the change in import penetration from China $(c)$ to eight other advanced countries $(o)$ for industry $k$ over period $\tau$. We include fixed effects for each year $\left(\gamma_{t}\right)$ and, in some regressions, Census division $\left(\gamma_{d}\right)$ and 1-digit SIC industry fixed effects $(F(k))$. Finally, the period over which we calculate the change in import penetration, $\tau$, is the period since an employer-union dyad's most recent contract was negotiated (which, as mentioned above, is typically three years). ${ }^{23}$ We cluster standard errors by industry $k$.

Table 7 reports our results. We report estimates from Equation 9 that condition on fixed effects for each year (Column 1), plus each Census division (Column 2), plus each 1-digit SIC code (Column 3), plus the industry's initial 1989 unionization rate (Column 4). The coefficients are remarkably stable across columns; in Column 4, our richest model, the coefficient implies that a 1 percentage point increase in industry trade exposure over the course of an expiring contract leads unions to negotiate for 0.12 percent lower wage increases $(\exp (-0.131)-1=-0.122, p=.022)$.

These results imply that greater industry exposure to the "China Shock" did in fact lead to a reduction in rents that unions could extract from employers, reducing the wage gains that unions were able to secure.

\subsection{Effect of Local Labor Market Exposure on Union-Negotiated Wage Increases}

To examine the overall effect of local labor market exposure on union-negotiated wage increases, we estimate the following regression:

\footnotetext{
${ }^{23}$ Specifically, for contracts settled between employer-union dyads for which we observe a prior contract settled between that dyad, we measure (and annualize) the change in trade exposure since the year of the prior contract. Among contracts for which we do not observe a prior settlement for the relevant dyad, we calculate the change in trade exposure over the prior three years, which is the average duration of contracts in our data.
} 


$$
\ln \left(w_{j k t}\right)=\beta_{1} \Delta I P_{j \tau}^{C Z}+\gamma_{t}+\gamma_{r(j)}+F(k)+\beta_{2} X_{j 0}+\epsilon_{j k t},
$$

where $\ln \left(w_{j k t}\right)$ is the $\log$ of the percent wage increase negotiated between an employer-union dyad located in $\mathrm{CZ} j$, doing business in industry $k$, negotiated in year $t . \Delta I P_{j \tau}^{C Z}$ is as defined above-the average import penetration of industries located in $\mathrm{CZ} j$, which we instrument with $\Delta I P_{j \tau}^{c o}$. We condition on a combination of fixed effects for year, Census division, and 1-digit SIC codes $\left(\gamma_{t}, \gamma_{r(j)}, F(k)\right)$. We also include start-of-period CZ controls, including the percent of employment in manufacturing. We cluster standard errors by commuting zone.

We report estimates of $\beta_{1}$ from Equation 10 in Table 8, with varying levels of controls. Across each specification, higher local labor market exposure has no detectable effect on the average wage increases negotiated by unions; if anything the point estimates are positive. As discussed in Section 4.1, this non-effect is consistent with prior work which finds that unionnegotiated wages are largely a function of quasi-rents to be shared, rather than changes in workers' outside option.

Within manufacturing, however, our measure of local labor market exposure to import competition also captures the degree of establishments' direct exposure (via their industry). To isolate the effect of indirect exposure, we again classify observations into the three mutually-exclusive categories of Exposed, Non-exposed tradable, and Non-exposed nontradable, described in Section 3.2, and we interact $\Delta I P_{j \tau}^{C Z}$ with indicators for these three sectors to estimate the differential effect of local labor market exposure across these sectors, analogous to Equation 6.

In Table A3, we report estimates that consider differential effects of local labor market exposure by sector. For both non-tradeable and tradeable non-exposed industries - those for which our measure of local labor market exposure purely captures indirect exposure to import penetration - the point estimates on $\Delta I P_{j \tau}^{C Z}$ are actually positive, and for non- 
exposed tradeables are actually statistically significant. ${ }^{24}$ For exposed industries, the point estimate on $\triangle I P_{j \tau}^{C Z}$ is always negative and statistically significant in three of the five columns, consistent with the industry-level analysis. These results illustrate that greater local labor market exposure to import competition did not negatively affect unions' ability to extract wage increases.

At the same time, much prior work has found that greater local labor market exposure led to substantial decreases in the market wage. Indeed, in Table 9, we report estimates, similar to those first found by Autor et al. (2013), of the effect of local labor market exposure to Chinese import exposure on overall (market) wages. Here, the dependent variable is the decadal log change in the average weekly wages in a $\mathrm{CZ}$, and the independent variable is the decadal change in the CZ's import exposure. Greater local labor market exposure to the China Shock led to a substantial reduction in overall wages. Furthermore, local labor market exposure led to a sharp reduction in employment rates Autor et al. (2013); ?); Acemoglu et al. (2016).

Collectively, this set of results suggests that local labor market exposure to the China Shock made workers reluctant to organize for union representation not by affecting the benefits of unionization (the union wage premium), but rather by increasing the perceived cost of organizing (the wage reduction a worker could expect in the event of job loss).

\section{Conclusion}

Worker attempts to organize labor unions, reflected in the number of union certification elections, have fallen sharply in the last few decades. The literature has provided surprisingly little explanatory evidence for this puzzling trend. We show that the surge in Chinese imports into the US beginning in the 1990s accounted for a meaningful share of the decline in union organizing over this period through two channels. The "China Shock" led to lower

\footnotetext{
${ }^{24}$ We do not read too closely into the statistical significance of the coefficients for Non-exposed tradeables. For one, these interactions are somewhat underpowered. Additionally, the significance does not withstand other sensible regression specifications (results not shown).
} 
union organizing both among workers in industries that faced direct exposure to competition from growing Chinese imports, as well as those in local labor markets where a large share of firms (even if not a worker's own) faced exposure to imports. We propose and present supporting evidence for the mechanisms by which these two types of exposure affected organizing: direct industry exposure eroded the expected wage gains from union representation, whereas indirect local labor market exposure raised the cost of job loss.

Our results inform a puzzle in labor economics that has been called the "representation gap": if workers' stated desire for unionization has been steadily high over the last few decades (Kochan et al., 2019), why are fewer and fewer workers organizing to seek union representation? Undoubtedly, forces outside the scope of this paper, such as legal and political hostility to organized labor (Stansbury, 2021), have played a role. Our paper offers evidence for another partial explanation. As international trade has weakened many workers' labor market prospects, it has increased the costs associated with job loss - which union organizing makes more likely. Thus, a growing number of workers may have become reluctant to seek union representation, even if their benefits of doing could be large. At the same time, our paper reveals that some portion of the decline in organizing may also reflect declining benefits of unionization for some workers, particularly those working in sectors where trade and other forces have decreased the rents available for unions to extract.

It is well-documented that wages have stagnated for the majority of U.S. workers in recent decades. A key question in labor economics is the degree to which this trend is driven by fundamentals (such as the rise in international trade or skill-biased technical change) versus institutions (such as the decline in labor unions). One final implication of our paper is that these explanations are not necessarily mutually exclusive. We find that the rise in Chinese import competition (one of the "fundamentals") led to a decline in workers' efforts to organize for unions (one of the "institutions"), which may have interacted with and compounded each other to affect changes in the wage structure. 


\section{References}

Abowd, John A and Thomas Lemieux, "The effects of product market competition on collective bargaining agreements: The case of foreign competition in Canada," The Quarterly Journal of Economics, 1993, 108 (4), 983-1014.

Abowd, John M and Henry S Farber, "Product Market Competition, Union Organizing Activity, and Employer Resistence," Technical Report, National Bureau of Economic Research 1990.

Acemoglu, Daron, David Autor, David Dorn, Gordon H Hanson, and Brendan Price, "Import competition and the great US employment sag of the 2000s," Journal of Labor Economics, 2016, 34 (S1), S141-S198.

Ahlquist, John S and Mitch Downey, "Import Exposure and Unionization in the United States," Technical Report, Working paper, UC San Diego Center for Commerce and Diplomacy 2019.

Ashenfelter, Orley and John H. Pencavel, "Trade Union Growth: 1900-1960," The Quarterly Journal of Economics, 1969, 83 (3), 434-448.

Autor, David, David Dorn, Gordon H Hanson, Gary Pisano, Pian Shu et al., "Foreign competition and domestic innovation: Evidence from US patents," American Economic Review: Insights, 2020, 2 (3), 357-74.

Bloom, Nicholas, Kyle Handley, Andre Kurman, and Phillip Luck, "The impact of chinese trade on us employment: The good, the bad, and the debatable," Unpublished draft, 2019.

Bronfenbrenner, Kate, "No holds barred: The intensification of employer opposition to organizing," Economic Policy Institute, 2009. 
Card, David, "The effect of unions on the structure of wages: A longitudinal analysis," Econometrica: Journal of the Econometric Society, 1996, pp. 957-979.

David, H Autor, David Dorn, and Gordon H Hanson, "The China syndrome: Local labor market effects of import competition in the United States," American Economic Review, 2013, 103 (6), 2121-68.

Farber, Henry S, "The recent decline of unionization in the United States," Science, 1987, 238 (4829), 915-920.

_ and Daniel H Saks, "Why workers want unions: The role of relative wages and job characteristics," Journal of Political Economy, 1980, 88 (2), 349-369.

_, Daniel Herbst, Ilyana Kuziemko, and Suresh Naidu, "Unions and inequality over the twentieth century: New evidence from survey data," Technical Report, National Bureau of Economic Research 2018.

Frandsen, Brigham R, "The surprising impacts of unionization: Evidence from matched employer-employee data," Journal of Labor Economics, 2021, 39 (4), 000-000.

Freeman, Richard B and James L Medoff, "What do unions do," Indus. E3 Lab. Rel. Rev., 1984, 38, 244.

Hirsch, Barry T, "Sluggish institutions in a dynamic world: Can unions and industrial competition coexist?," Journal of Economic Perspectives, 2008, 22 (1), 153-176.

- and David A Macpherson, "Union membership and coverage database from the current population survey: Note," ILR Review, 2003, 56 (2), 349-354.

Jacobson, Louis S, Robert J LaLonde, and Daniel G Sullivan, "Earnings losses of displaced workers," The American economic review, 1993, pp. 685-709.

Knepper, Matthew, "From the Fringe to the Fore: Labor Unions and Employee Compensation," Review of Economics and Statistics, 2020, 102 (1), 98-112. 
Kochan, Thomas A, Duanyi Yang, William T Kimball, and Erin L Kelly, "Worker voice in America: Is there a gap between what workers expect and what they experience?," ILR Review, 2019, 72 (1), 3-38.

Lachowska, Marta, Alexandre Mas, and Stephen A Woodbury, "Sources of displaced workers' long-term earnings losses," Technical Report, National Bureau of Economic Research 2018.

Lazear, Edward P, "A competitive theory of monopoly unionism," Technical Report, National Bureau of Economic Research 1981.

Lee, David S and Alexandre Mas, "Long-run impacts of unions on firms: New evidence from financial markets, 1961-1999," The Quarterly Journal of Economics, 2012, 127 (1), 333-378.

McNicholas, Celine, Margaret Poydock, Julia Wolfe, Ben Zipperer, Gordon Lafer, and Lola Loustaunau, "Unlawful: US employers are charged with violating federal law in $41.5 \%$ of all union election campaigns," Economic Policy Institute: Washington, DC, USA, 2019.

Mishel, Lawrence, Lynn Rhinehart, and Lane Windham, "Explaining the erosion of private-sector unions," Economic Policy Institute, 2020.

Pierce, Justin R and Peter K Schott, "The surprisingly swift decline of US manufacturing employment," American Economic Review, 2016, 106 (7), 1632-62.

_ and _, "Trade liberalization and mortality: evidence from US counties," American Economic Review: Insights, 2020, 2 (1), 47-64.

Rose, Nancy L, "Labor rent sharing and regulation: Evidence from the trucking industry," Journal of Political Economy, 1987, 95 (6), 1146-1178. 
Sheflin, Neil, Leo Troy, and C. Timothy Koeller, "Structural Stability in Models of Union Growth," The Quarterly Journal of Economics, 1981, 96 (1), 77-88.

Slaughter, Matthew J, "Globalization and declining unionization in the United States," Industrial Relations: A Journal of Economy and Society, 2007, 46 (2), 329-346.

Stansbury, Anna, "Do US Firms Have an Incentive To Comply With the FLSA and the NLRA?," Peterson Institute for International Economics Working Paper, 2021, (21-9).

Tolbert, Charles M and Molly Sizer, "US commuting zones and labor market areas: A 1990 update," Technical Report 1996.

Wasi, Nada and Aaron Flaaen, "Record linkage using Stata: Preprocessing, linking, and reviewing utilities," The Stata Journal, 2015, 15 (3), 672-697. 


\section{$7 \quad$ Tables and Figures}

Figure 1: Annual Rates of Union Organizing Elections

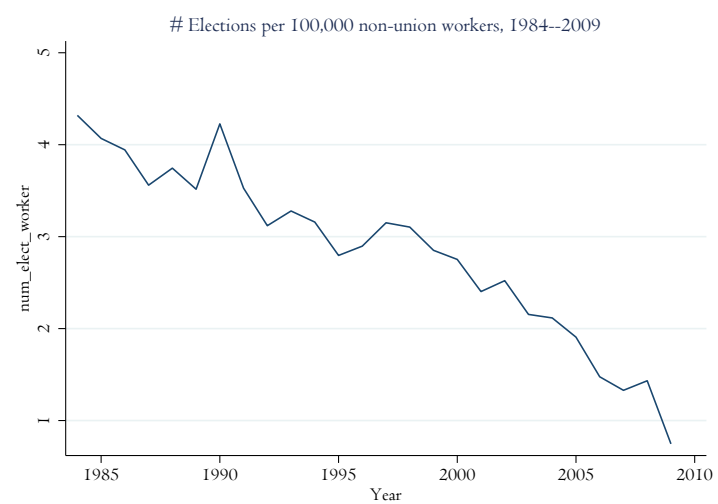

(a) Number of certification elections per 100,000 non-union workers, 1984-2009

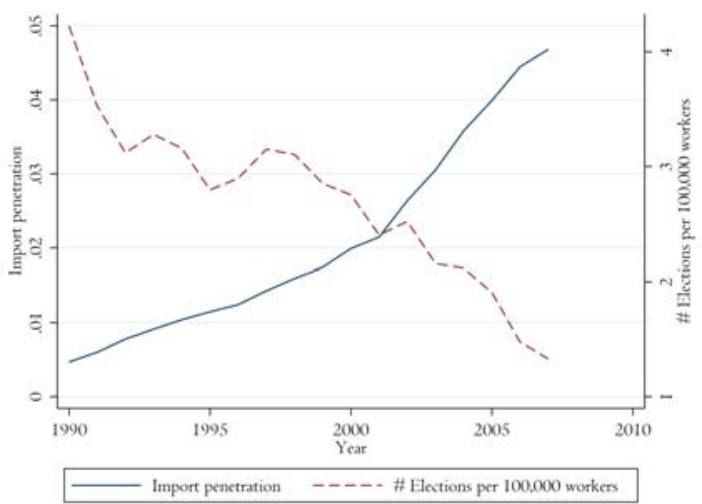

(b) Number of elections per 100,000 non-union workers and Chinese import penetration, 1990-2007

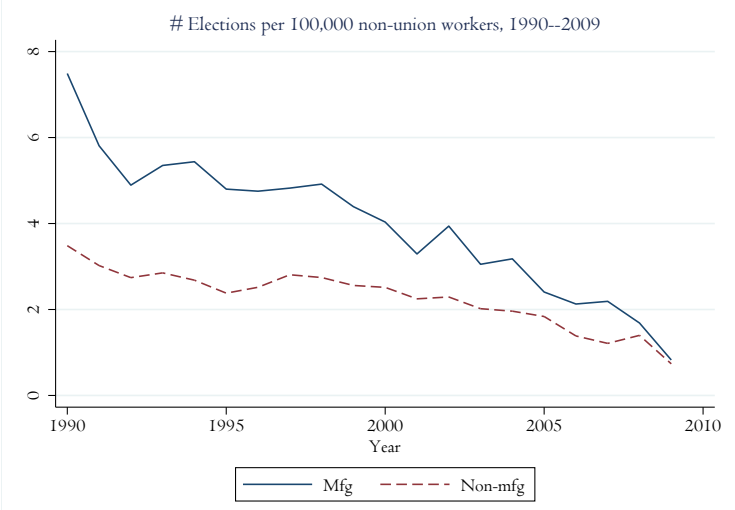

(c) Number of election per 100,000

non-union workers by sector, 1990-2007

Notes: Elections taking place in Puerto Rico, U.S. Virgin Islands, and Guam are not reported. Data on number of non-union workers in each year are from unionstats.com, a website maintained by Barry $\mathrm{T}$. Hirsch and David A. Macpherson, which uses data from the Current Population Survey Monthly Outgoing Rotation Group (CPS-MORG). 
Table 1: Union Election Summary Statistics

1990-1999 2000-2007 All Years

\section{Entire U.S.}

\# of Elections Overall per Decade

$29,131 \quad 17,817 \quad 23,474$

\# of Elections per 10,000 Workers per Decade

$\begin{array}{lll}2.75 & 1.41 & 2.08\end{array}$

Share of Elections among Manufacturing Establishments

$0.25 \quad 0.20 \quad 0.23$

Share of Elections Won per Decade (\%)

$\begin{array}{lll}0.50 & 0.58 & 0.54\end{array}$

Mean \# of Eligible Employees in Elections

$67.62 \quad 74.36$

70.99

\section{Industry-level variables ( $\mathrm{N}=392$ 4-digit SIC Manufacturing Industries)}

\# of Elections per 4-digit SIC per Decade

13.82

7.37

10.59

$(25.51)$

\# of Elections per 10,000 Workers per 4-digit SIC per Decade

3.55

2.01

2.78

$\Delta$ Industry Import Exposure

Local labor market variables ( $\mathrm{N}=722$ Commuting Zones (CZs))

\# of Elections per CZ per Decade

$$
40.35
$$

\# of Elections per 10,000 Workers per CZ per Decade

$\begin{array}{ccc}2.40 & 1.11 & 1.75 \\ (2.21) & (1.25) & (1.91) \\ 0.07 & 0.14 & 0.10 \\ (0.09) & (0.13) & (0.12)\end{array}$

Notes: The table reports variable means, as well as standard deviations in parentheses. Elections taking place in Hawaii, Alaska, Puerto Rico, U.S. Virgin Islands, and Guam are not reported. Data on number of workers per CZ in 1990 and 2000 are from the Quarterly Census of

Employment and Wages (QCEW). Data on number of workers per 4-digit SIC code in 1990 and 2000 is from the County Business Patterns $(\mathrm{CBP})$ data files. 
Table 2: The Effect of Industry Exposure to Import Competition on Rate of Union Organizing Elections

\begin{tabular}{lcccc}
\hline & $(1)$ & $(2)$ & $(3)$ & $(4)$ \\
& Log Elections & Log Elections & Log Elections & Log Wins \\
& per 10,000 & per 10,000 & per 10,000 & per 10,000 \\
workers & workers & workers & workers \\
& Mfg & Mfg & Mfg & Mfg \\
\hline VARIABLES & & & & \\
& & & & \\
$\Delta$ Industry Import Exposure & $-0.031^{* * *}$ & $-0.026^{* * *}$ & $-0.025^{* *}$ & $-0.025^{* * *}$ \\
& {$[0.010]$} & {$[0.010]$} & {$[0.010]$} & {$[0.008]$} \\
& & & & \\
Observations & 784 & 784 & 784 & 784 \\
$R^{2}$ & 0.061 & 0.145 & 0.154 & 0.172 \\
Spec & OLS & OLS & OLS & OLS \\
Decade FE & $\mathrm{Y}$ & $\mathrm{Y}$ & $\mathrm{Y}$ & $\mathrm{Y}$ \\
1989 Unionization & $\mathrm{N}$ & $\mathrm{Y}$ & $\mathrm{Y}$ & $\mathrm{Y}$ \\
1-digit SIC FE & $\mathrm{N}$ & $\mathrm{N}$ & $\mathrm{Y}$ & $\mathrm{Y}$ \\
\# SIC Codes & 392 & 392 & 392 & 392 \\
Mean \# elections / wins & 0.341 & 0.341 & 0.341 & 0.133 \\
\hline
\end{tabular}

Notes: N=784 (392 manufacturing industries x 2 time periods). All regressions include a constant. Robust standard errors in parentheses are clustered at the 4-digit SIC code level. Models are weighted by start of period (1990 or 2000) 4-digit SIC employment levels. Outcome variable is reported per 10,000 workers in each 4-digit SIC code at the start period (1990 or 2000). Import shocks are annualized. Elections taking place in Hawaii, Alaska, Puerto Rico, U.S. Virgin Islands, and Guam are not reported. Data on number of workers per 4 -digit SIC code in 1990 and 2000 is from the County Business Patterns (CBP) data files. 1989 unionization rates by 4-digit SIC code are from CPS-MORG. 
Table 3: The Effect of Local Labor Market Exposure to Import Competition on Rate of Union Organizing Elections

(3)

(4)

Log Elections Log Elections Log Elections Log Elections Log Wins

\begin{tabular}{|c|c|c|c|c|c|}
\hline & $\begin{array}{c}\text { per } 10,000 \\
\text { workers }\end{array}$ & $\begin{array}{c}\text { per } 10,000 \\
\text { workers }\end{array}$ & $\begin{array}{c}\text { per } 10,000 \\
\text { workers }\end{array}$ & $\begin{array}{c}\text { per } 10,000 \\
\text { workers }\end{array}$ & $\begin{array}{c}\text { per } 10,000 \\
\text { workers }\end{array}$ \\
\hline VARIABLES & Total & Total & Total & Total & Total \\
\hline \multirow[t]{2}{*}{ Normalized $\Delta$ Imports } & $-0.298^{* *}$ & $-0.259^{* * *}$ & $-0.289^{* * *}$ & $-0.259^{* * *}$ & $-0.234^{* * *}$ \\
\hline & {$[0.122]$} & {$[0.051]$} & {$[0.047]$} & {$[0.074]$} & {$[0.078]$} \\
\hline Observations & 1,444 & 1,444 & 1,444 & 1,444 & 1,444 \\
\hline$R^{2}$ & 0.128 & 0.591 & 0.601 & 0.603 & 0.568 \\
\hline spec & OLS & OLS & OLS & OLS & OLS \\
\hline Decade FE & $\mathrm{Y}$ & $\mathrm{Y}$ & $\mathrm{Y}$ & $\mathrm{Y}$ & $\mathrm{Y}$ \\
\hline 1989 Unionization & $\mathrm{N}$ & $\mathrm{Y}$ & $\mathrm{Y}$ & $\mathrm{Y}$ & $\mathrm{Y}$ \\
\hline Census Region FE & $\mathrm{N}$ & $\mathrm{N}$ & $\mathrm{Y}$ & $\mathrm{Y}$ & $\mathrm{Y}$ \\
\hline Pct employed in $\mathrm{mfg}$ & $\mathrm{N}$ & $\mathrm{N}$ & $\mathrm{N}$ & $\mathrm{Y}$ & $\mathrm{Y}$ \\
\hline \# commuting zones & 722 & 722 & 722 & 722 & 722 \\
\hline Mean \# elections per worker & 0.212 & 0.212 & 0.212 & 0.212 & 0.108 \\
\hline
\end{tabular}

Notes: $\mathrm{N}=1,444$ (722 CZs x 2 time periods). All regressions include a constant. Robust standard errors in parentheses are clustered at the state level. Models are weighted by start of period (1990 or 2000) CZ employment levels. Outcome variable is reported per 10,000 workers in each CZ at the start period (1990 or 2000). Import shocks are annualized. Elections taking place in Hawaii, Alaska, Puerto Rico, U.S. Virgin Islands, and Guam are not reported. Data on start of period (1990) share of employment in manufacturing are from the Quarterly Census of Employment and Wages (QCEW). 1989 unionization rates by state are from CPS-MORG. 
Table 4: The Effect of Local Labor Market Exposure to Import Competition on Rate of Union Organizing Elections, by Sector

(1)

(3)

(4)

Log Elections Log Elections Log Elections Log Elections

VARIABLES per 10,000 per 10,000 per 10,000 per 10,000

workers workers workers workers

\begin{tabular}{lcccc}
$\Delta$ Imports $\times 1$ Exposed $\}$ & $-0.494^{* * *}$ & $-0.461^{* * *}$ & $-0.488^{* * *}$ & $-0.427^{* * *}$ \\
& {$[0.106]$} & {$[0.084]$} & {$[0.080]$} & {$[0.096]$} \\
$\Delta$ Imports $\times 1$ Nonexposed Tradable\} & $-0.220^{* *}$ & $-0.187^{* *}$ & $-0.214^{* *}$ & -0.153 \\
& {$[0.096]$} & {$[0.086]$} & {$[0.084]$} & {$[0.100]$} \\
$\Delta$ Imports $\times 1$ Nonexposed Nontradable\} & $-0.305^{* *}$ & $-0.272^{* * *}$ & $-0.299^{* * *}$ & $-0.238^{* * *}$ \\
& {$[0.120]$} & {$[0.062]$} & {$[0.061]$} & {$[0.080]$} \\
& & & & 4,332 \\
Observations & 4,332 & 4,332 & 4,332 & 0.427 \\
$R^{2}$ & 0.157 & 0.414 & 0.421 & OLS \\
spec & OLS & OLS & OLS & $\mathrm{Y}$ \\
Decade FE & $\mathrm{Y}$ & $\mathrm{Y}$ & $\mathrm{Y}$ & $\mathrm{Y}$ \\
1989 Unionization & $\mathrm{N}$ & $\mathrm{Y}$ & $\mathrm{Y}$ & $\mathrm{Y}$ \\
Census Region FE & $\mathrm{N}$ & $\mathrm{N}$ & $\mathrm{Y}$ & $\mathrm{Y}$ \\
Pct employed in mfg & $\mathrm{N}$ & $\mathrm{N}$ & 722 & 722 \\
\# commuting zones & 722 & 722 & $\mathrm{~N}$ & \\
\hline
\end{tabular}

Notes: $\mathrm{N}=4,332$ (722 CZs x 2 time periods x 3 sectors). All regressions include a constant. Robust standard errors in parentheses are clustered at the state level. Models are weighted by start of period (1990 or 2000) CZ employment levels. All models also control for indicators for the three sectors. Outcome variable is reported per 10,000 workers in each sector and CZ at the start period (1990 or 2000). Import shocks are annualized Elections taking place in Hawaii, Alaska, Puerto Rico, U.S. Virgin Islands, and Guam are not reported. Data on start of period (1990) share of employment in manufacturing are from the Quarterly Census of Employment and Wages (QCEW). 1989 unionization rates by state are from CPS-MORG. 
Table 5: How Many More Union Certification Elections Would There Have Been Absent the "China Shock'?

(1)

Decade Weighted \# of Elections $\quad$ Predicted Weighted \# of Elections $\%$ Difference

Industry-level Counterfactuals

$1990-1999$

3.08

$2000-2007$

1.69

1.80

$1990-2007$

4.77

4.99

$-4.45$

\section{CZ-level Counterfactuals}

$\begin{array}{lccr}1990-1999 & 2.74 & 2.95 & -7.35 \\ 2000-2007 & 1.53 & 1.73 & -11.18 \\ 1990-2007 & 4.27 & 4.68 & -8.76\end{array}$

Notes: The table reports the number of elections per 10,000 workers and the number of elections per 10,000 workers that would have occurred in the absence of industry-level and CZ-level import shocks in each decadal period of analysis. Means across industries and commuting zones are weighted by the number of workers in each CZ and 4-digit SIC code at the start of the decade (1990 and 2000 respectively). Elections taking place in Hawaii, Alaska, Puerto Rico, U.S. Virgin Islands, and Guam are not reported. Data on number of workers per CZ in 1990 and 2000 are from the Quarterly Census of Employment and Wages (QCEW). Data on number of workers per 4-digit SIC code in 1990 and 2000 is from the County Business Patterns (CBP) data files. 
Table 6: Union Contract Settlements: Summary Statistics

\begin{tabular}{lccc}
\hline & $(1)$ & $(2)$ & $(3)$ \\
& $1990-1999$ & $2000-2007$ & All Years \\
\hline All Industries & & & \\
\% Wage Increase & 4.13 & 3.70 & 3.84 \\
& $(4.54)$ & $(3.97)$ & $(4.18)$ \\
Contract Duration & 3.46 & 3.46 & 3.46 \\
& $(1.25)$ & $(1.19)$ & $(1.21)$ \\
Observations & 1593 & 3179 & 4772 \\
& & & \\
Manufacturing & & & \\
\% Wage Increase & 3.91 & 3.57 & 3.72 \\
& $(4.49)$ & $(2.74)$ & $(3.63)$ \\
Contract Duration & 3.53 & 3.58 & 3.56 \\
& $(1.31)$ & $(1.18)$ & $(1.24)$ \\
Observations & 974 & 1202 & 2176 \\
& & & \\
Non-Manufacturing & & & \\
\% Wage Increase & 4.50 & 3.77 & 3.94 \\
& $(4.59)$ & $(4.57)$ & $(4.58)$ \\
Contract Duration & 3.36 & 3.39 & 3.38 \\
& $(1.16)$ & $(1.19)$ & $(1.18)$ \\
Observations & 619 & 1977 & 2596 \\
& & & \\
\hline
\end{tabular}

Notes:The table reports variable means and standard deviations in parantheses. Contract data from the Bloomberg Bureau of NationalAffairs (BNA) Labor Plus database. 
Table 7: The Effect of Industry Exposure to Import Competition on Union-Negotiated Wage Increases

\begin{tabular}{lcccc}
\hline & $\begin{array}{c}(1) \\
\text { Log Wage } \\
\text { Increase }\end{array}$ & $\begin{array}{c}\text { Log Wage } \\
\text { Increase }\end{array}$ & $\begin{array}{c}\text { Log Wage } \\
\text { Increase }\end{array}$ & $\begin{array}{c}\text { Log Wage } \\
\text { Increase }\end{array}$ \\
\hline & & & & \\
$\Delta$ Industry Import Exposure & $-0.125^{* *}$ & $-0.117^{* *}$ & $-0.130^{* *}$ & $-0.131^{* *}$ \\
& {$[0.058]$} & {$[0.057]$} & {$[0.060]$} & {$[0.062]$} \\
& & & & \\
Observations & 2,143 & 2,143 & 2,143 & 2,143 \\
$R^{2}$ & 0.034 & 0.044 & 0.048 & 0.048 \\
Spec & OLS & OLS & OLS & OLS \\
Year FE & $\mathrm{Y}$ & $\mathrm{Y}$ & $\mathrm{Y}$ & $\mathrm{Y}$ \\
Census FE & $\mathrm{N}$ & $\mathrm{Y}$ & $\mathrm{Y}$ & $\mathrm{Y}$ \\
1-digit SIC FE & $\mathrm{N}$ & $\mathrm{N}$ & $\mathrm{Y}$ & $\mathrm{Y}$ \\
1989 Unionization & $\mathrm{N}$ & $\mathrm{N}$ & $\mathrm{N}$ & $\mathrm{Y}$ \\
\# SIC Codes & 295 & 295 & 295 & 295 \\
\# Unique Contracts & 2143 & 2143 & 2143 & 2143 \\
Mean Log Wage & 1.059 & 1.059 & 1.059 & 1.059 \\
\hline
\end{tabular}

Robust standard errors in brackets

$* * * \mathrm{p}<0.01,{ }^{* *} \mathrm{p}<0.05, * \mathrm{p}<0.1$

Notes: All regressions include a constant. Robust standard errors in parentheses are clustered at the 4-digit SIC code level. Import shocks are annualized. The start year of the first iteration of a series of contracts (and contracts not occurring in dyads) is taken to be 3 years before the negotiation year or 1991, whichever is greater. 1989 unionization rates by 4-digit SIC code are from CPS-MORG. 
Table 8: The Effect of Local Labor Market Exposure to Import Competition on UnionNegotiated Wage Increases

\begin{tabular}{|c|c|c|c|c|c|}
\hline VARIABLES & $\begin{array}{c}(1) \\
\text { Log Wage } \\
\text { Increase }\end{array}$ & $\begin{array}{c}(2) \\
\text { Log Wage } \\
\text { Increase }\end{array}$ & $\begin{array}{c}(3) \\
\text { Log Wage } \\
\text { Increase }\end{array}$ & $\begin{array}{c}(4) \\
\text { Log Wage } \\
\text { Increase }\end{array}$ & $\begin{array}{c}(5) \\
\text { Log Wage } \\
\text { Increase }\end{array}$ \\
\hline \multirow[t]{2}{*}{$\Delta \mathrm{CZ}$ Import Exposure } & 0.080 & 0.226 & 0.228 & 0.176 & 0.554 \\
\hline & {$[0.223]$} & {$[0.237]$} & {$[0.243]$} & {$[0.206]$} & {$[0.343]$} \\
\hline Observations & 8,288 & 8,288 & 8,288 & 8,288 & 8,288 \\
\hline$R^{2}$ & 0.018 & 0.069 & 0.069 & 0.076 & 0.074 \\
\hline Spec & OLS & OLS & OLS & OLS & OLS \\
\hline Year FE & $\mathrm{Y}$ & $\mathrm{Y}$ & $\mathrm{Y}$ & $\mathrm{Y}$ & $\mathrm{Y}$ \\
\hline 1-digit SIC FE & $\mathrm{N}$ & $\mathrm{Y}$ & $\mathrm{Y}$ & $\mathrm{Y}$ & $\mathrm{Y}$ \\
\hline 1989 Unionization & $\mathrm{N}$ & $\mathrm{N}$ & $\mathrm{Y}$ & $\mathrm{Y}$ & $\mathrm{Y}$ \\
\hline Census FE & $\mathrm{N}$ & $\mathrm{N}$ & $\mathrm{N}$ & $\mathrm{Y}$ & $\mathrm{Y}$ \\
\hline \# Commuting Zones & 432 & 432 & 432 & 432 & 432 \\
\hline \# Unique Contracts & 7295 & 7295 & 7295 & 7295 & 7295 \\
\hline Mean Wage Increase & 4.113 & 4.113 & 4.113 & 4.113 & 4.113 \\
\hline
\end{tabular}

Notes: All regressions include a constant. Robust standard errors in parentheses are clustered at the state level. Import shocks are annualized. Only contracts which span 5 or fewer commuting zones are considered. The start year of the first iteration of a series of contracts (and contracts not occurring in dyads) is taken to be 3 years before the negotiation year or 1991, whichever is greater. Data on start of period (1990) share of employment in manufacturing are from the Quarterly Census of Employment and Wages (QCEW). 1989 unionization rates by state are from CPS-MORG. 
Table 9: The Effect of Local Labor Market Exposure to Import Competition on the Market Wage (from Acemoglu et al. (2016))

\begin{tabular}{lcccc}
\hline & $(1)$ & $(2)$ & $(3)$ & $(4)$ \\
& Chg in & Chg in & Chg in & Chg in \\
& Log Wages & Log Wages & Log Wages & Log Wages \\
VARIABLES & Overall & Overall & Overall & Overall \\
\hline & & & & \\
Normalized $\Delta$ Imports & $-11.013^{* *}$ & $-12.813^{* * *}$ & $-13.006^{* * *}$ & -8.767 \\
& {$[5.062]$} & {$[4.544]$} & {$[4.547]$} & {$[7.776]$} \\
& & & & \\
Observations & 1,444 & 1,444 & 1,444 & 1,444 \\
$R^{2}$ & 0.503 & 0.540 & 0.540 & 0.544 \\
Decade FE & $\mathrm{Y}$ & $\mathrm{Y}$ & $\mathrm{Y}$ & $\mathrm{Y}$ \\
Census Region FE & $\mathrm{N}$ & $\mathrm{Y}$ & $\mathrm{Y}$ & $\mathrm{Y}$ \\
1989 Unionization & $\mathrm{N}$ & $\mathrm{N}$ & $\mathrm{Y}$ & $\mathrm{Y}$ \\
Pct employed in mfg & $\mathrm{N}$ & $\mathrm{N}$ & $\mathrm{N}$ & $\mathrm{Y}$ \\
\# commuting zones & 722 & 722 & 722 & 722 \\
\hline
\end{tabular}

Notes:The table reports changes in average log weekly wages. Wage data for 1990 and 2000 are from the Census Integrated Public Use Micro Samples and the American Community Survey (ACS) for 2006 and 2008. Import shocks are annualized. Wage changes across commuting zones are weighted by the number of workers in each CZ and 4-digit SIC code at the start of the decade (1990 and 2000 respectively). Data on number of workers per CZ in 1990 and 2000 are from the Quarterly Census of Employment and Wages (QCEW). Robust standard errors in parentheses are clustered on state. 


\section{Appendix}

\section{A More Details on Constructing the Union Contract Settlements}

\section{Identifying Repeat Observations of the Same Employer-Union Dyad}

We then identify such repeat observations as follows. First, we manually cleaned the employer names to standardize different spellings and naming conventions across contracts and ensure the same establishments are not erroneously treated as separate entities. Second, we treated establishments that re-branded, changed names after going public, or were otherwise acquired by another company as the same employer in an employer-union dyad. ${ }^{25}$ Finally, we eliminated duplicate contracts. ${ }^{26}$

\section{Standardization of Negotiated Wage Increases}

Here, we provide further details to how we constructed our variable measuring the wage increase negotiated in a union contract settlement. As described in the main text, this variable is the sum of two components: a main wage increase and any remaining wage increases in the form of bonuses or other lump-sum payments.

When a wage increase is provided as a range, we take the midpoint of the range. For contracts that span multiple years, if the value assigned to one of the years is blank we fill it in by extending the value of the previous year. When increases are assigned to a specific date in MM-DD-YY format, we convert the date to a year indexed relative to the start year of the contract and do not consider the month and date of payment.

For the first component, wage increases in the settlements are reported sometimes as dollar increases, other times as percentage increases; increases are also reported over various spans including hourly, weekly, monthly or annual wages. We standardized these reports to an average annual percent increase relative to the baseline hourly wage. For the second component, we first converted the annual dollar amounts to an hourly wage increase assuming a 40-hour workweek and 52 working weeks per year, and we then converted these hourly increases to percentage increases relative to the baseline hourly wages. Since most contracts do not provide information on the original hourly wages negotiated in prior contracts, we

\footnotetext{
${ }^{25}$ We manually looked up companies for any IPOs, re-branding, acquisitions and mergers and adjusted the name to reflect the most recent naming convention.

${ }^{26}$ In the data, we observed 122 contracts that were each exact duplicates of another contract. Furthermore, we eliminated 68 contracts that were identical to another contract except for minor punctuation and wording differences. Finally, we observed 17 contracts that were identical in employer, union, negotiation year, location, number and type of workers, and "main" wage increase described below but did not include bonus payments or lump-sum payments. We treated these contracts as erroneously missing the lump-sum payments and omitted them from our analysis.
} 
created contract-specific baseline wages using the average hourly wages for union members in manufacturing or non-manufacturing by year as reported in the CPS Merged Outgoing Rotation Groups (MORG) data set.

To arrive at the final wage increase value, we take the mean percentage wage increase of each of our two components over the duration of the contract, and we then sum up the two means .

One example is illustrative. One clause in our data, a 5-year contract that begins in 1995 associated with a non-manufacturing establishment, read: "None initially, 2nd yr, \$0.15-0.25 per hr 5-1-97, 5-1-98, 5-1-99, \$300-700 lump-sum 5-1-95, 5-1-96, 5-1-97". We consider this clause in two parts, the first part containing the clause prior to the phrase "\$300-700 lumpsum" and the second part containing the remaining section of the clause. We converted the string in the first part to a succession of annual wage increases in dollars by extending the "None" in year 1 onto the 2nd year that is blank and taking the midpoint of the range of increases for years 3, 4, and 5 (corresponding to 1997, 1998, and 1999 for this contract). This gives us the sequential annual increases in hourly wage in dollars: $\$ 0.00$ in year $1, \$ 0.00$ in year $2, \$ 0.20$ in year $3, \$ 0.20$ in year $4, \$ 0.20$ in year 5 . Next, we link this contract with the average hourly wages for unionized workers in non-manufacturing sectors in years 1995 through 1999 from the MORG data set $(\$ 16.15, \$ 16.55, \$ 17.07, \$ 17.62$, and $\$ 18.34$ per hour, respectively). We use these wages from the MORG data set as "baseline wages" for each of the years 1995 through 1999 and convert the dollar increases into percentage increases. We thus obtain the sequential annual increases in percentages: $0.00 \%$ in year $1,0.00 \%$ in year $2,1.17 \%$ in year $3,1.14 \%$ in year $4,1.09 \%$ in year 5 . Taking the average percentage increase over the 5-year period gives an increase of approximately $0.7 \%$.

For the second section of the clause, we converted the string to a succession of annual wage increases in dollars by taking the midpoint of $\$ 300$ and $\$ 700$. This gives us the sequential annual increases in dollars: $\$ 500$ in year $1, \$ 500$ in year $2, \$ 500$ in year, $\$ 0$ in year $4, \$ 0$ in year 5. Converting these to hourly wage increases assuming a 40-hour work week and 52 weeks worked per year gives: $\$ 0.24$ in year $1, \$ 0.24$ in year $2, \$ 0.24$ in year, $\$ 0.00$ in year $4, \$ 0.00$ in year 5 . Lastly, we convert these to percentage increases relative to the baseline wages: $1.48 \%$ in year $1,1.45 \%$ in year $2,1.40 \%$ in year, $0.00 \%$ in year $4,0.00 \%$ in year 5 . Taking the average percentage increase over the 5 -year period gives an increase of approximately $0.9 \%$.

Next, we arrive at the $\Delta$ Wage Increase $\%$ variable by taking the sum of the two average percentage increases to get $1.5 \%=0.7 \%+0.9 \%$. 


\section{B Appendix Tables and Figures}

Figure A1: Distribution of Negotiated Wage Increases, 1991-2008

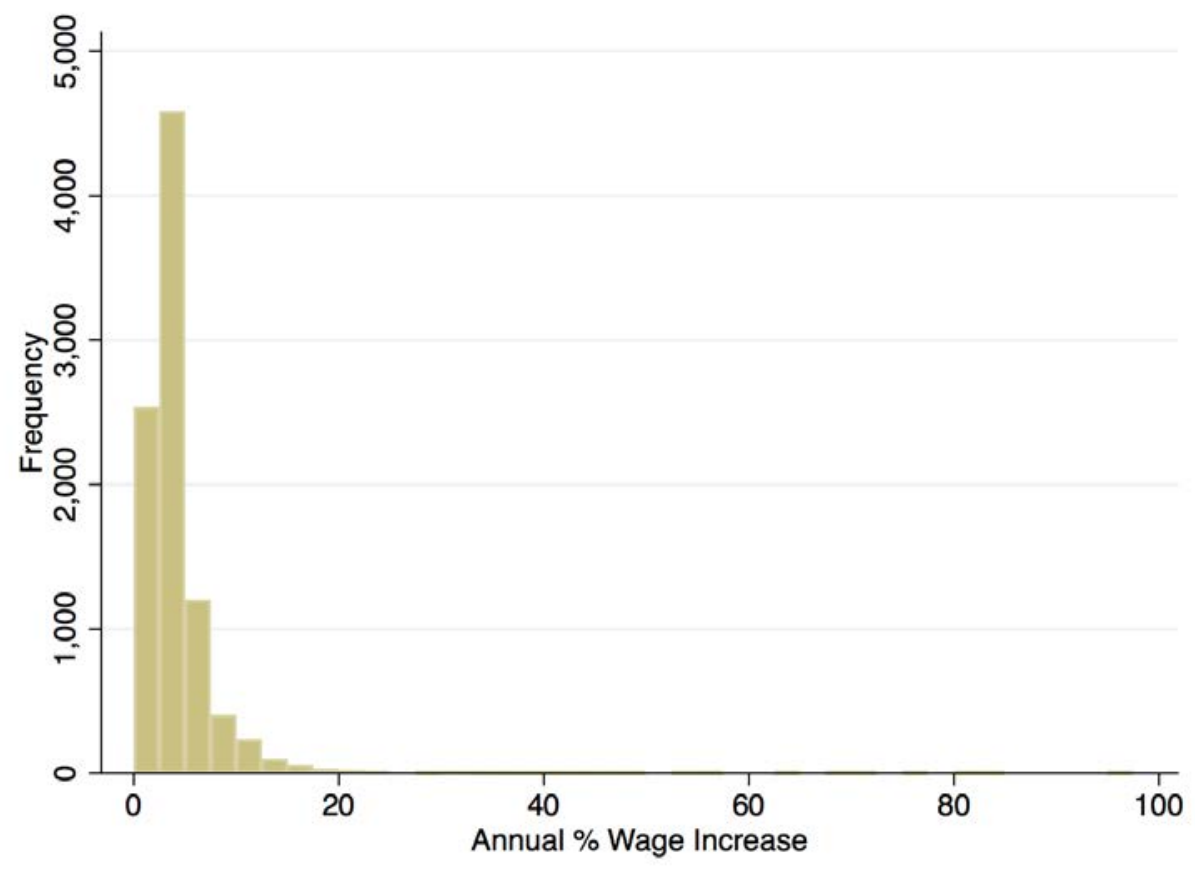

Notes: Distribution of all \% hourly wage increases observed in private contract settlements between 1991 and 2008 in the BNA database. Wage increases include lump-sum payments such as bonuses, see Appendix for further details on methodology. 
Table A1: Pierce-Schott Specification: the Effect of Industry Exposure to Import Competition on Rate of Union Organizing Elections

(1) (2) (3)

\begin{tabular}{lcccc}
\hline & $(1)$ & $(2)$ & $(3)$ & $(4)$ \\
& Log Elections & Log Elections & Log Elections & Log Wins per \\
& per 10,000 & per 10,000 & per 10,000 & per 10,000 \\
workers & workers & workers & workers \\
VARIABLES & Mfg & Mfg & Mfg & Mfg \\
\hline & & & & \\
Post x NTR Gap & $-1.272^{* * *}$ & $-1.269^{* * *}$ & $-0.984^{* * *}$ & $-0.896^{* * *}$ \\
& {$[0.300]$} & {$[0.299]$} & {$[0.301]$} & {$[0.265]$} \\
& & & & \\
Observations & 6,664 & 6,664 & 6,664 & 6,664 \\
$R^{2}$ & 0.070 & 0.070 & 0.107 & 0.051 \\
Spec & OLS & OLS & OLS & OLS \\
Year FE & $\mathrm{Y}$ & $\mathrm{Y}$ & $\mathrm{Y}$ & $\mathrm{Y}$ \\
1989 Unionization & $\mathrm{N}$ & $\mathrm{Y}$ & $\mathrm{Y}$ & $\mathrm{Y}$ \\
1-digit SIC FE & $\mathrm{N}$ & $\mathrm{N}$ & $\mathrm{Y}$ & $\mathrm{Y}$ \\
\# SIC Codes & 392 & 392 & 392 & 392 \\
Mean \# elections $/$ wins & 0.292 & 0.292 & 0.292 & 0.113 \\
\hline
\end{tabular}

Notes:: $\mathrm{N}=6,664$ (392 manufacturing industries x 17 years). All regressions include a constant. The dependent variable is the log of industry-year number of elections in manufacturing sectors and the independent variable representing the effect of PNTR is the interaction of the NTR gap and a post-PNTR indicator. Data span 1991-2007. Robust standard errors adjusted for clustering at the industry (4-digit SIC code) level are displayed below each coefficient. Models are weighted by start of period (1990) 4-digit SIC employment levels. Outcome variable is reported per 10,000 workers in each 4-digit SIC code at the start period (1990). Elections taking place in Hawaii, Alaska, Puerto Rico, U.S. Virgin Islands, and Guam are not reported. Data on number of workers per 4-digit SIC code in 1990 is from the County Business Patterns (CBP) data files. 1989 unionization rates by 4-digit SIC code are from CPS-MORG. 
Table A2: Pierce-Schott Specification: the Effect of Local Labor Market Exposure to Import Competition on Rate of Union Organizing Elections

\begin{tabular}{lccccc}
\hline & $\begin{array}{c}(1) \\
\text { Log Elections } \\
\text { per } 10000 \\
\text { Total }\end{array}$ & $\begin{array}{c}\text { Log Elections } \\
\text { per } 10000 \\
\text { Total }\end{array}$ & $\begin{array}{c}\text { Log Elections } \\
\text { per } 10000 \\
\text { Total }\end{array}$ & $\begin{array}{c}\text { Log Elections } \\
\text { per } 10000 \\
\text { Total }\end{array}$ & $\begin{array}{c}\text { Log Wins } \\
\text { per } 10000 \\
\text { Total }\end{array}$ \\
\hline \multirow{2}{*}{ VARIABLES } & & & & & \\
Post x NTR Gap & $-6.448^{* * *}$ & $-5.956^{* * *}$ & $-7.118^{* * *}$ & $-4.892^{* * *}$ & $-4.619^{* * *}$ \\
& {$[1.701]$} & {$[0.871]$} & {$[1.008]$} & {$[1.331]$} & {$[1.487]$} \\
Observations & & & & & \\
$R^{2}$ & 12,274 & 12,274 & 12,274 & 12,274 & 12,274 \\
spec & 0.079 & 0.192 & 0.343 & 0.350 & 0.306 \\
Year FE & OLS & OLS & OLS & OLS & OLS \\
1989 Unionization & $\mathrm{Y}$ & $\mathrm{Y}$ & $\mathrm{Y}$ & $\mathrm{Y}$ & $\mathrm{Y}$ \\
Census Region FE & $\mathrm{N}$ & $\mathrm{Y}$ & $\mathrm{Y}$ & $\mathrm{Y}$ & $\mathrm{Y}$ \\
Pct employed in mfg & $\mathrm{N}$ & $\mathrm{N}$ & $\mathrm{Y}$ & $\mathrm{Y}$ & $\mathrm{Y}$ \\
\# commuting zones & $\mathrm{N}$ & $\mathrm{N}$ & $\mathrm{N}$ & $\mathrm{Y}$ & $\mathrm{Y}$ \\
Mean \# elections / wins & 0.195 & 0.195 & 0.195 & 0.195 & 0.195 \\
\hline
\end{tabular}

Notes:: $\mathrm{N}=12,274$ (722 commuting zones x 17 years). All regressions include a constant. The dependent variable is the log of industry-year number of elections and the independent variable representing the effect of PNTR is the interaction of the NTR gap and a post-PNTR indicator. Data span 1991-2007. Robust standard errors adjusted for clustering at the state level are displayed below each coefficient. Models are weighted by start of period (1990) commuting zone employment levels. Outcome variable is reported per 10,000 workers in each commuting zone at the start period (1990). Elections taking place in Hawaii, Alaska, Puerto Rico, U.S. Virgin Islands, and Guam are not reported. Data on start of period (1990) share of employment in manufacturing are from the Quarterly Census of Employment and Wages (QCEW). 1989 unionization rates by state are from CPS-MORG. 
Table A3: The Effect of Local Labor Market Exposure to Import Competition on UnionNegotiated Wage Increases, by Sector

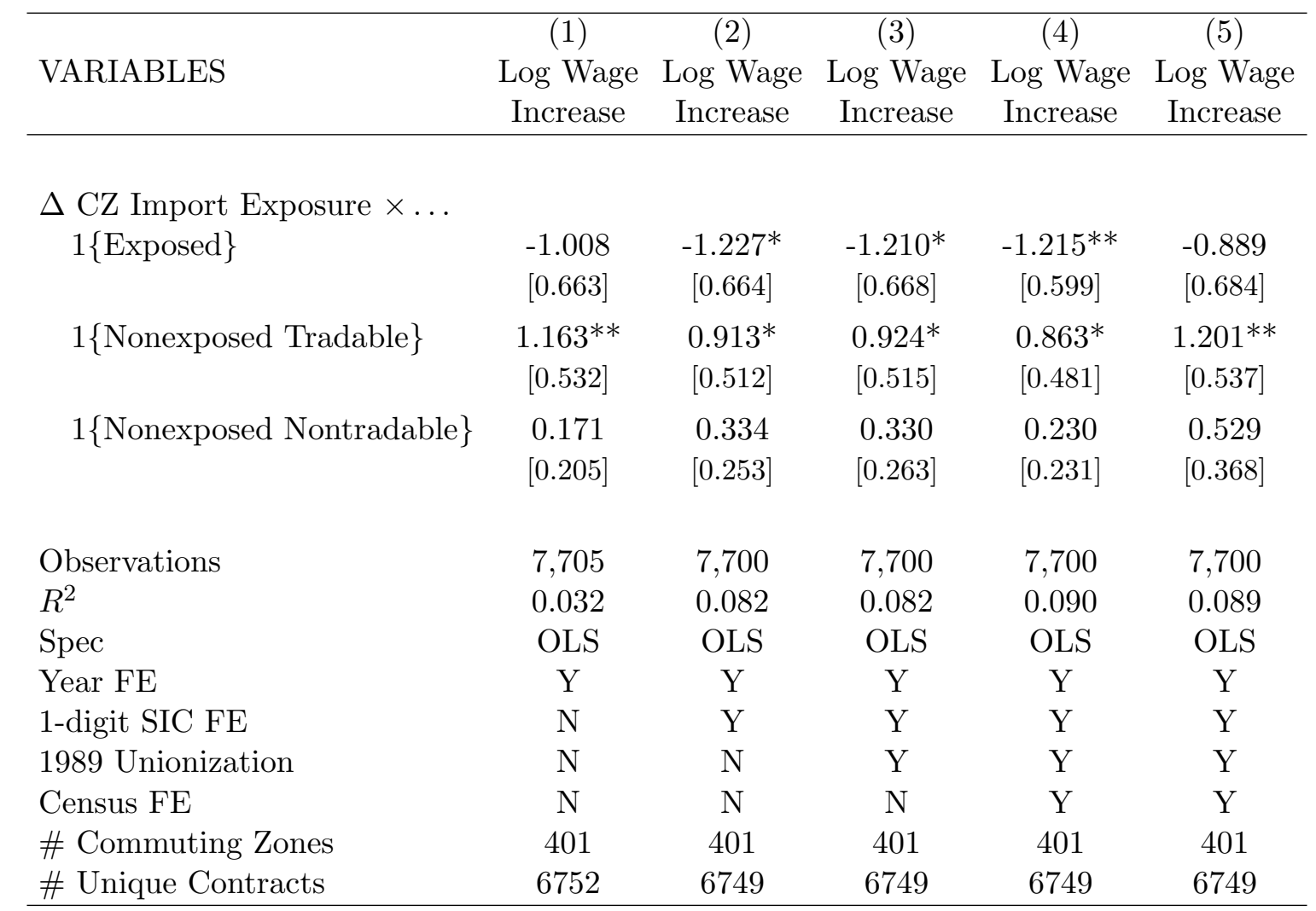

Robust standard errors in brackets

$* * * \mathrm{p}<0.01,{ }^{* *} \mathrm{p}<0.05,{ }^{*} \mathrm{p}<0.1$

Notes: $\mathrm{N}=7,705$ which is slightly smaller compared to Table 8 because we exclude manufacturing contracts that we were unable to link to 4 -digit SIC codes from this table's analysis. All regressions include a constant. Robust standard errors in parentheses are clustered at the state level. All models also control for indicators for the three sectors. Import shocks are annualized. Only contracts that span 5 or fewer commuting zones are included. The start year of the first iteration of a series of contracts (and contracts not occurring in dyads) is taken to be 3 years before the negotiation year or 1991, whichever is greater. Data on start of period (1990) share of employment in manufacturing are from the Quarterly Census of Employment and Wages (QCEW). 1989 unionization rates by state are from CPS-MORG. 
Table A4: Contract Settlements: Industry Exposure Based on Contract Durations

\begin{tabular}{lcccc}
\hline & $\begin{array}{c}(1) \\
\text { Log Wage } \\
\text { Increase }\end{array}$ & $\begin{array}{c}\text { Log Wage } \\
\text { Increase }\end{array}$ & $\begin{array}{c}\text { Log Wage } \\
\text { Increase }\end{array}$ & $\begin{array}{c}\text { Log Wage } \\
\text { Increase }\end{array}$ \\
\hline VARIABLES & & & & \\
$\Delta$ Industry Import Exposure & $-0.106^{* *}$ & $-0.099^{*}$ & $-0.110^{* *}$ & $-0.110^{* *}$ \\
& {$[0.053]$} & {$[0.051]$} & {$[0.054]$} & {$[0.055]$} \\
& & & & \\
Observations & 2,143 & 2,143 & 2,143 & 2,143 \\
$R^{2}$ & 0.031 & 0.042 & 0.045 & 0.045 \\
Spec & OLS & OLS & OLS & OLS \\
Year FE & $\mathrm{Y}$ & $\mathrm{Y}$ & $\mathrm{Y}$ & $\mathrm{Y}$ \\
Census FE & $\mathrm{N}$ & $\mathrm{Y}$ & $\mathrm{Y}$ & $\mathrm{Y}$ \\
1-digit SIC FE & $\mathrm{N}$ & $\mathrm{N}$ & $\mathrm{Y}$ & $\mathrm{Y}$ \\
1989 Unionization & $\mathrm{N}$ & $\mathrm{N}$ & $\mathrm{N}$ & $\mathrm{Y}$ \\
\# SIC Codes & 295 & 295 & 295 & 295 \\
\# Unique Contracts & 2143 & 2143 & 2143 & 2143 \\
Mean Log Wage & 1.059 & 1.059 & 1.059 & 1.059 \\
\hline
\end{tabular}

Robust standard errors in brackets

$* * * \mathrm{p}<0.01,{ }^{* *} \mathrm{p}<0.05,{ }^{*} \mathrm{p}<0.1$

Notes: All regressions include a constant. Robust standard errors in parentheses are clustered at the 4-digit SIC code level. All import shocks begin at the negotiation year of the contract minus the duration of the contract or 1991, whichever is greater. All import shocks end at the negotiation year of the contract. Import shocks are annualized. 1989 unionization rates by 4-digit SIC code are from CPS-MORG. 
Table A5: Contract Settlements: Geographic Exposure Based on Contract Durations

\begin{tabular}{lccccc}
\hline & $\begin{array}{c}(1) \\
\text { Log Wage } \\
\text { Increase }\end{array}$ & $\begin{array}{c}\text { Log Wage } \\
\text { Increase }\end{array}$ & $\begin{array}{c}(3) \\
\text { Log Wage } \\
\text { Increase }\end{array}$ & $\begin{array}{c}\text { Log Wage } \\
\text { Increase }\end{array}$ & $\begin{array}{c}\text { Log Wage } \\
\text { Increase }\end{array}$ \\
\hline \multirow{4}{*}{$\Delta$ CZ Import Exposure } & -0.123 & 0.092 & 0.097 & 0.050 & 0.419 \\
& {$[0.283]$} & {$[0.294]$} & {$[0.298]$} & {$[0.255]$} & {$[0.383]$} \\
& & & & & \\
Observations & 8,288 & 8,288 & 8,288 & 8,288 & 8,288 \\
$R^{2}$ & 0.020 & 0.070 & 0.070 & 0.076 & 0.076 \\
Spec & $\mathrm{OLS}$ & OLS & OLS & OLS & OLS \\
Year FE & $\mathrm{Y}$ & $\mathrm{Y}$ & $\mathrm{Y}$ & $\mathrm{Y}$ & $\mathrm{Y}$ \\
1-digit SIC FE & $\mathrm{N}$ & $\mathrm{Y}$ & $\mathrm{Y}$ & $\mathrm{Y}$ & $\mathrm{Y}$ \\
1989 Unionization & $\mathrm{N}$ & $\mathrm{N}$ & $\mathrm{Y}$ & $\mathrm{Y}$ & $\mathrm{Y}$ \\
Census FE & $\mathrm{N}$ & $\mathrm{N}$ & $\mathrm{N}$ & $\mathrm{Y}$ & $\mathrm{Y}$ \\
\# Commuting Zones & 432 & 432 & 432 & 432 & 432 \\
\# Unique Contracts & 7295 & 7295 & 7295 & 7295 & 7295 \\
Mean Wage Increase & 4.113 & 4.113 & 4.113 & 4.113 & 4.113 \\
\hline
\end{tabular}

Notes: All regressions include a constant. Robust standard errors in parentheses are clustered at the state level. All import shocks begin at the negotiation year of the contract minus the duration of the contract or 1991, whichever is greater. All import shocks end at the negotiation year of the contract. Import shocks are annualized. 1989 unionization rates by state are from CPS-MORG. 